\title{
Inferring nitrification rates with an inverse method in a coastal upwelling system, Ría de Vigo (NW Spain)
}

\author{
X. A. Álvarez-Salgado*, M. Gilcoto \\ Consejo Superior de Investigaciones Cientificas, Insituto de Investigacións Mariñas, Eduardo Cabello 6, 36208 Vigo, Spain
}

\begin{abstract}
Net ecosystem ammonification and nitrification rates were estimated in the inner and outer segments of the coastal upwelling system of the Ría de Vigo during September 1990 and 1991. A multiparameter inverse method was used, combining short-time-scale changes ( 2 to $4 \mathrm{~d}$ ) in the distributions of salinity, temperature, ammonium, nitrite, nitrate and dissolved oxygen with freshwater and heat budgets for the embayment. The robustness of the calculations has been assessed by random perturbation of the measured variables within the limits of their oceanographic errors. During September 1990, when a complete coastal upwelling/downwelling cycle of $\sim 2$ wk was sampled (average surface outgoing velocity in the middle ría, $v=+0.3 \mathrm{~km} \mathrm{~d}^{-1}$ ), nitrogen regeneration was limited in the lower layer of the ría and the only relevant process was ammonification: average $0.1 \mathrm{mmol} \mathrm{m}^{-3}$ $\mathrm{d}^{-1}$, increasing from $0.0 \mathrm{mmol} \mathrm{m}^{-3} \mathrm{~d}^{-1}$ from 14 to 18 September to $0.3 \mathrm{mmol} \mathrm{m}^{-3} \mathrm{~d}^{-1}$ from 24 to $27 \mathrm{Sep}$ tember. Concomitantly, nitrogen assimilation rates in the upper layer were low, average -0.2 and $-0.1 \mathrm{mmol} \mathrm{m}^{-3} \mathrm{~d}^{-1}$ in the inner and outer segments, respectively. Conversely, during September 1991, when coastal upwelling was dominant $\left(v=+1.8 \mathrm{~km} \mathrm{~d}^{-1}\right)$, nitrogen regeneration rates in the lower layer were much larger: average ammonification was $0.2 \mathrm{mmol} \mathrm{m}^{-3} \mathrm{~d}^{-1}$ in the outer and $0.6 \mathrm{mmol} \mathrm{m}^{-3}$ $\mathrm{d}^{-1}$ in the inner ría. Nitrification was also remarkably intense: $\sim 70 \%$ of the regenerated ammonium was oxidized to nitrite and $\sim 90 \%$ of the regenerated nitrite was oxidized to nitrate in the inner segment, whereas $100 \%$ of the regenerated ammonium was converted to nitrate in the outer segment. These nitrogen regeneration rates were accompanied by intense nitrogen assimilation in the upper layer of the inner (average $-1.3 \mathrm{mmol} \mathrm{m}^{-3} \mathrm{~d}^{-1}$ ) and outer (average $-0.6 \mathrm{mmol} \mathrm{m}{ }^{-3} \mathrm{~d}^{-1}$ ) segments, $\sim 60 \%$ of which was based on nitrate and the remaining $\sim 40 \%$ on ammonium assimilation. Consequently, regeneration processes in the lower layer provided $\sim 50 \%$ of the nitrate and $\sim 30 \%$ of the ammonium assimilated in the upper layer.
\end{abstract}

KEY WORDS: Ammonification · Nitrification $\cdot$ Upwelling $\cdot$ Downwelling $\cdot$ NW Spain

Resale or republication not permitted without written consent of the publisher

\section{INTRODUCTION}

Nitrogen mineralization consists of the conversion of amino nitrogen into ammonium, which is subsequently oxidized to nitrite and, finally, to nitrate, the most stable nitrogen form under the usually oxidative conditions of natural waters (Wada \& Hattori 1991). Dissolved oxygen is consumed during the oxidation of organic carbon to $\mathrm{CO}_{2}$ and during the oxidation of ammonium to nitrate (nitrification). As a consequence of either intense nitrification rates or prolonged residence times, dissolved oxygen in the water column and the sediments can be depleted, leading to $\mathrm{N}_{2}$ production (denitrification; Wada \& Hattori 1991). Denitri- fication occurs mainly in sediments because of the concurrence of high organic loads and poor ventilation (Klump \& Martens 1983, Middleburg et al. 1993).

Nitrifying bacteria, known of since Winogradsky (1890), are limited by ammonia, and photoinhibition ensures that little nitrification can occur in the photic zone; however, nitrifying activity increases sharply below this zone (Olson 1981, Ward et al. 1982, Guerrero \& Jones 1996a,b). Nitrification is especially intense in coastal areas, due to enhanced primary production of organic nitrogen in response to enrichment from the atmosphere, the continental runoff and the ocean (Wollast 1993). Atmospheric and continental N inputs are significant in highly populated and industri- 
alized countries, whereas the surrounding ocean waters are the primary N-nutrient source in coastal upwelling regions (Codispoti 1983, Smith \& Hollibaugh 1993, Wollast 1993).

The measurement of nitrification rates has been approached by way of culture and field experiments, the latter involving either in vitro or in situ methods. The laboratory decomposition studies of von Brand et al. $(1937,1939,1940,1941,1942)$ and von Brand \& Rakestraw $(1940,1941)$ demonstrated that phytoplankton is able to close the $\mathrm{N}$ cycle by transforming nitrate into organic nitrogen, which can undergo bacterial decomposition a second time, and that temperature has a crucial effect on nitrification rates. However, the experiments of von Brand et al., as well as those by Watson (1965), Yoshida (1967) and Carlucci \& Strickland (1968), showed that cultured marine nitrifying bacteria grow and/or oxidize their substrates very slowly compared with the observed nitrite and nitrate accumulations in the sea (Ward 1982, Kaplan 1983). In contrast to extensive laboratory studies, little work has been done under natural field conditions (Harrison 1980). Some of these studies showed that marine nitrifiers in nature can utilize their substrate at much lower levels than those observed in culture studies: Olson (1981) demonstrated that the half-saturation constants for ammonium and nitrite oxidation are $<0.1 \mu \mathrm{M}$.

In opposition to in vitro field studies, which are affected by reduced turbulence, unnatural light fields and altered grazer communities etc., the possibility of an in situ determination of nitrification rates exists by means of inverse methods, which can produce reliable results by combining the observation of short-timescale changes in $\mathrm{N}$-species distributions with a box model of the system. Conversely, inverse methods can only estimate net ammonification and nitrification rates and might involve large potential errors, but they constitute a unique method for measuring the ecosystem metabolism directly (Smith \& Hollibaugh 1997). Therefore, box model estimations of rate measurements are probably less precise than in vitro techniques, but the resultant values are ready for direct interpretation at the ecosystem level.

Nitrogen species distributions in the NW Iberian upwelling system have been known about since the 1960s, after the pioneering works of Fraga and colleagues in the Ría de Vigo and adjacent shelf waters (Fraga 1960, 1961, 1967, Fraga \& Vives 1961). These studies placed a special emphasis on the dissolved and suspended organic nitrogen fractions. N-nutrient distributions were the subject of subsequent works in the adjacent Ría de Arousa during the 1970s (e.g. Iglesias \& Nunes 1982, Cabanas et al. 1983) and the Ría de Vigo during the 1980s and 1990s (Nogueria et al. 1997, 1998), when the crucial effect of both seasonal and short- time-scale cycles of coastal upwelling-relaxationdownwelling on the N-nutrient distributions was unequivocally demonstrated. Primitive inverse methods have been used to study the nitrogen cycle in the rías (González et al. 1979, Prego 1994). However, they were based on individual surveys, which do not allow running of the box model under non-steady-state conditions, a prerequisite for accounting the upwellingrelaxation cycles of ca. 1 to 2 wk periods (ÁlvarezSalgado et al. 1993). On the other hand, the nonsteady-state approach of Álvarez-Salgado et al. (1996) was not concerned with nitrification. Therefore, the objective of this work was to quantify the short time (2 to $4 \mathrm{~d}$ ) and space (inner vs outer) variability of net production/consumption rates of ammonium, nitrite and nitrate in the Ría de Vigo during September, when Nnutrient regeneration should be high in this area (Nogueria et al. 1997). This research was carried out by means of the multiparameter non-steady-state inverse method OERFIM recently presented by Gilcoto et al. (2001), with special emphasis on ammonification and nitrification.

\section{MATERIALS AND METHODS}

Data set. Data used to run the inverse model were obtained from 3 sources (Fig. 1): (1) the meteorological station at the airport of Vigo; (2) the buoy deployed at Stn 3 ; and (3) the hydrographic surveys carried out at Stns 1, 2, 3, 4, 5 and 9 on 14, 18, 20, 24 and 27 September 1990 and 9, 13, 16, 19, 24 and 26 September 1991 aboard RV 'Explorador'. The meteorological station at the airport provided data on rainfall $\left(P, \mathrm{~m}^{3} \mathrm{~s}^{-1}\right)$ and cloudiness $(N$, oktas). Cloudiness is necessary to calculate the heat exchange flux across the sea surface (Álvarez-Salgado et al. 2000). Continental runoff $\left(Q_{\mathrm{R}}\right)$ was computed from precipitation (Ríos et al. 1992). The buoy at Stn 3 provided local winds ( $W_{\mathrm{X}}$ and $W_{\mathrm{Y}}$ ) with an Aanderaa 2740 sensor. At the hydrographic stations, full-depth continuous conductivity and temperature profiles were recorded with a calibrated CTD SBE-25. Salinity was calculated from the CTD-conductivity record with the equation by UNESCO (1985). The accuracies of CTD salinity and temperature were \pm 0.005 and $\pm 0.005^{\circ} \mathrm{C}$, respectively. Dissolved oxygen and $\mathrm{N}$-nutrients were measured at 5 to 7 selected depths throughout the water column at each station. Dissolved oxygen was analyzed by Winkler potentiometric endpoint titration, with an estimated analytical

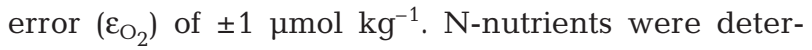
mined by segmented flow analysis following Hansen \& Grashoff (1983) with some small improvements (Mouriño \& Fraga 1985). The corresponding analytical errors were $\varepsilon_{\mathrm{NH}_{4}}= \pm 0.05 \mu \mathrm{M} \mathrm{N}, \varepsilon_{\mathrm{NO}_{2}}= \pm 0.02 \mu \mathrm{M} \mathrm{N}$ and 


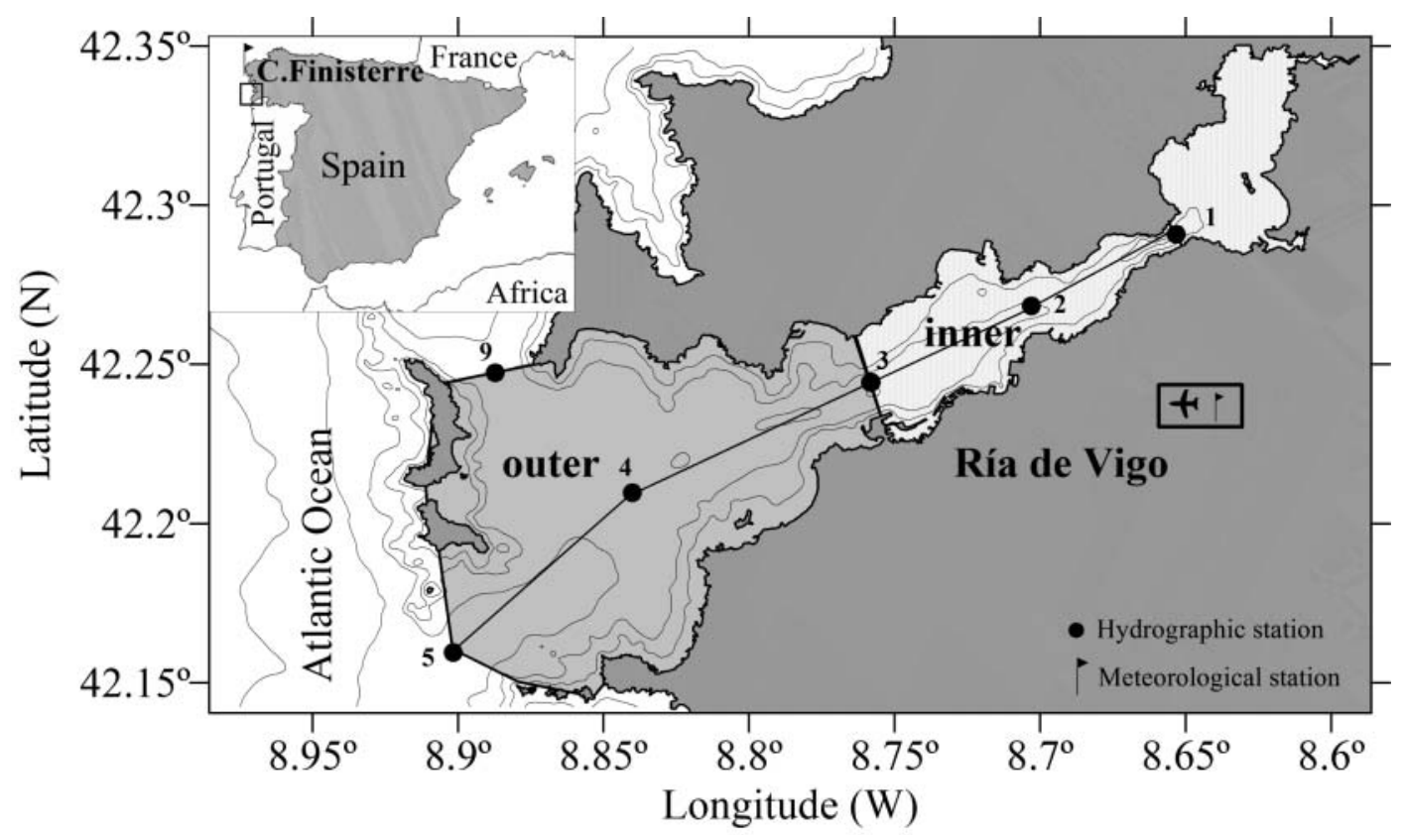

Fig. 1. Chart of the Ría de Vigo (NW Spain) with the 5 sampling sites visited during September 1990 and 1991 (black dots) and the 2 study boxes: the 'inner' and 'outer' ría

$\varepsilon_{\mathrm{NO}_{3}}= \pm 0.1 \mu \mathrm{M}$ N. Air temperature $\left(T_{\mathrm{A}},{ }^{\circ} \mathrm{C}\right)$ and relative humidity $(h, \%)$ were taken from on board the ship to calculate the evaporation flux $\left(\mathrm{m}^{3} \mathrm{~s}^{-1}\right)$ with a parametric equation (Álvarez-Salgado et al. 2000).

Ammonification. Ammonium is produced by either oxidative or non-oxidative deamination of amino acids and by hydrolysis of amides, with the microbial food web being largely responsible for these processes in the ocean (e.g. Legendre \& Rassoulzadegan 1995). A simple chemical model based on the decomposition of biogenic organic matter with an average chemical formula $\mathrm{C}_{106} \mathrm{H}_{175} \mathrm{O}_{42} \mathrm{~N}_{16} \mathrm{P}$ has been used. This formula represents a material formed by $54.5 \%$ of proteins, $25.5 \%$ of carbohydrates, $16.1 \%$ of lipids and $4.0 \%$ of nucleic acids (Anderson 1995):

$$
\begin{gathered}
\mathrm{C}_{106} \mathrm{H}_{175} \mathrm{O}_{44} \mathrm{~N}_{16} \mathrm{P}+116 \mathrm{O}_{2}+46 \mathrm{H}_{2} \mathrm{O} \\
\stackrel{K_{\text {org }}}{\longrightarrow} \\
106 \mathrm{HCO}_{3}{ }^{-}+16 \mathrm{NH}_{4}{ }^{+}+\mathrm{HPO}_{4}{ }^{2-}+94 \mathrm{H}^{+}
\end{gathered}
$$

Consumption of $116 \mathrm{~mol}$ of dissolved oxygen occurs to produce $16 \mathrm{~mol}$ of ammonium. $K_{\text {org }}$ (in $\mu \mathrm{M} \mathrm{N} \mathrm{d}^{-1}$ ) is the rate constant associated with this process. Ammonium assimilation to produce organic nitrogen (reverse of Eq. 1) is mediated by photo- and chemoautotrophs. A negative value of $K_{\text {org }}$ indicates reversal of Eq. 1, i.e. dominance of organic nitrogen production over decomposition processes.

Nitrification. The conversion of ammonium into nitrate occurs in 2 steps (e.g. Wada \& Hattori 1991). The first step is the conversion of ammonium into nitrite $\left(K_{1}, \mu \mathrm{M} \mathrm{N} \mathrm{d}^{-1}\right)$ and the second step is the conversion of nitrite into nitrate $\left(K_{2}, \mu \mathrm{M} \mathrm{N} \mathrm{d}^{-1}\right)$. These processes are conducted by chemoautotrophic bacteria, which obtain energy from oxidation of ammonia or nitrite and cell carbon from carbon dioxide. Consumption of 1.5 and $0.5 \mathrm{~mol}$ of dissolved oxygen occurs during the production of $1 \mathrm{~mol}$ of $\mathrm{NO}_{2}^{-}$and $\mathrm{NO}_{3}{ }^{-}$, respectively:

$$
\begin{aligned}
& \mathrm{NH}_{4}^{+}+3 / 2 \mathrm{O}_{2} \stackrel{K_{1}}{\longrightarrow} \mathrm{NO}_{2}^{-}+\mathrm{H}_{2} \mathrm{O}+2 \mathrm{H}^{+} \\
& \mathrm{NO}_{2}^{-}+\frac{1}{2} \mathrm{O}_{2} \stackrel{K_{2}}{\longrightarrow} \mathrm{NO}_{3}^{-}
\end{aligned}
$$

Nitrate reduction to produce nitrite (reverse of Eq. 3) and nitrite reduction to produce ammonium (reverse of Eq. 2) is also performed by photo- and chemoautotrophs aided by the specific enzymes nitrate and nitrite reductase, respectively (e.g. Wada \& Hattori 1991). Non-assimilatory ammonium production also occurs during denitrification processes (Klump \& Martens 1983, Wada \& Hattori 1991). In any case, negative values of $K_{1}$ and $K_{2}$ indicate reversals of Eqs. (2) \& (3).

The system of linear equations. The 2D multiparameter inverse method OERFIM for calculating estuarine residual fluxes and net ammonification and nitrification rates in a selected segment (box) of an estuary or a coastal inlet has been applied. OERFIM retains the optimum solution for a weighted system of property conservation equations following the mean squares criterion. Involved properties are volume, salinity, temperature, nutrients $\left(\mathrm{NH}_{4}{ }^{+}, \mathrm{NO}_{2}^{-}\right.$and $\left.\mathrm{NO}_{3}{ }^{-}\right)$and dissolved oxygen. The following system of 7 equations 
(conservation of volume, heat salt, ammonium, nitrite, nitrate and corrected oxygen) with 5 unknowns $\left(\overline{Q_{\mathrm{S}}}\right.$, $\bar{Q}_{\mathrm{B}}, \overline{\rho N O}_{3}, \overline{\rho N O}_{2}$ and ${\overline{\rho N H_{4}}}_{4}$ ) can be written for a box with a unique open boundary (Fig. 2):

$$
\begin{aligned}
\bar{Q}_{\mathrm{S}}-\bar{T}_{\mathrm{B}}-\bar{Q}_{\mathrm{R}}-\bar{P}+\bar{E} & =0+r_{\mathrm{Q}} \\
\bar{Q}_{\mathrm{S}} \times \bar{T}_{\mathrm{S}}-\bar{Q}_{\mathrm{B}} \times \bar{T}_{\mathrm{B}}-\bar{Q}_{\mathrm{R}} \times \bar{T}_{\mathrm{R}} & \\
& -\bar{P} \times \bar{T}_{\mathrm{A}}-\bar{H}+V \times \frac{\Delta T}{\Delta t}=0+r_{\mathrm{T}}
\end{aligned}
$$

$$
\begin{aligned}
\bar{Q}_{\mathrm{S}} \times \overline{\mathrm{NH}}_{4 \mathrm{~S}}-\bar{Q}_{\mathrm{B}} \times & \overline{\mathrm{NH}}_{4 \mathrm{~B}}-\left(\bar{Q}_{\mathrm{R}}+\bar{P}\right) \times \overline{\mathrm{NH}}_{4 \mathrm{R}} \\
& -\overline{\rho \mathrm{NH}}_{4}+V \times \frac{\Delta \mathrm{NH}_{4}}{\Delta t}=0+r_{\mathrm{NH}_{4}}
\end{aligned}
$$

$$
\begin{aligned}
\bar{Q}_{\mathrm{S}} \times \overline{\mathrm{NO}}_{2 \mathrm{~S}}-\bar{Q}_{\mathrm{B}} \times \overline{\mathrm{NO}}_{2 \mathrm{~B}}-\left(\bar{Q}_{\mathrm{R}}+\bar{P}\right) \times \overline{\mathrm{NO}}_{2 \mathrm{R}} \\
-\overline{\rho N O}_{2}+V \times \frac{\Delta \mathrm{NO}_{2}}{\Delta t}=0+r_{\mathrm{NO} 2}
\end{aligned}
$$

$$
\begin{aligned}
\bar{Q}_{\mathrm{S}} \times \overline{\mathrm{NO}}_{3 \mathrm{~S}}-\bar{Q}_{\mathrm{B}} \times \overline{\mathrm{NO}}_{3 \mathrm{~B}}-\left(\bar{Q}_{\mathrm{R}}+\bar{P}\right) \times \overline{\mathrm{NO}}_{3 \mathrm{R}} \\
-\overline{\rho \mathrm{NO}}_{3}+V \times \frac{\Delta \mathrm{NO}_{3}}{\Delta t}=0+r_{\mathrm{NO}_{3}}
\end{aligned}
$$$$
\bar{Q}_{\mathrm{S}} \times \overline{\mathrm{O}}_{2 \mathrm{cS}}-\bar{Q}_{\mathrm{B}} \times \overline{\mathrm{O}}_{2 \mathrm{cB}}-\left(\bar{Q}_{\mathrm{R}}-\bar{P}\right) \times \overline{\mathrm{O}}_{2 \mathrm{cR}}-\bar{F}_{\mathrm{O}_{2}}
$$$$
+R_{\mathrm{N}} \times\left({\overline{\rho \mathrm{NH}_{4}}}_{4}+{\overline{\rho \mathrm{NO}_{2}}}_{2}+\overline{\rho \mathrm{NO}}_{3}\right)+V \times \frac{\Delta \mathrm{O}_{2 \mathrm{c}}}{\Delta t}=0+r_{\mathrm{O} 2}
$$

In this paper, average quantities always refer to the average between measurements made in 2 consecutive samples, where $\overline{Q_{\mathrm{B}}}$ and $\overline{Q_{\mathrm{S}}}$ are the average advective fluxes across the bottom and surface open boundaries of the box $\left(\mathrm{m}^{3} \mathrm{~s}^{-1}\right), \overline{Q_{\mathrm{R}}}$ is the average continental runoff to the study box $\left(\mathrm{m}^{3} \mathrm{~s}^{-1}\right)$. $\bar{E}$ is the average evaporation across the free surface of the box $\left(\mathrm{m}^{3} \mathrm{~s}^{-1}\right), \bar{P}$ is the average precipitation on the free surface of the box $\left(\mathrm{m}^{3} \mathrm{~s}^{-1}\right), \bar{H}$ is the average heat exchange with the atmosphere across the free surface of the study volume surveys $\left({ }^{\circ} \mathrm{C} \mathrm{m}^{3} \mathrm{~s}^{-1}\right), \bar{T}_{\mathrm{B}}$ and $\bar{T}_{\mathrm{S}}$ are the average temperature of the bottom and surface open boundaries of the box $\left({ }^{\circ} \mathrm{C}\right), \bar{T}_{\mathrm{R}}$ is the average temperature of the continental runoff to the study volume $\left({ }^{\circ} \mathrm{C}\right), \bar{T}_{\mathrm{A}}$ is the average temperature of the precipitation over the free surface of the study volume (assumed air temperature, ${ }^{\circ} \mathrm{C}$ ) and $V \times(\Delta T / \Delta t)$ is the change of temperature into the study volume between 2 consecutive surveys $\left({ }^{\circ} \mathrm{C} \mathrm{m}^{3}\right.$ $\mathrm{s}^{-1}$ ). In the case of the salinity, $\mathrm{NH}_{4}{ }^{+}, \mathrm{NO}_{2}{ }^{-}, \mathrm{NO}_{3}{ }^{-}$and $\mathrm{O}_{2 \mathrm{c}}$ conservation equations, the meaning of the corresponding variables is the same as for temperature. $V$ is the volume of the box $\left(\mathrm{m}^{3}\right) . \overline{\rho N H}_{4}, \overline{\rho N O}_{2}$ and $\overline{\rho N O}_{3}$ are the average net ecosystem production of ammonium, nitrite and nitrate in the study volume $\left(\mathrm{mmol} \mathrm{N} \mathrm{s}^{-1}\right) . \mathrm{O}_{2 \mathrm{c}}$ is the corrected oxygen $\left(\mathrm{O}_{2}-0.5 \times \mathrm{NO}_{2}-2 \times \mathrm{NH}_{4}\right.$;

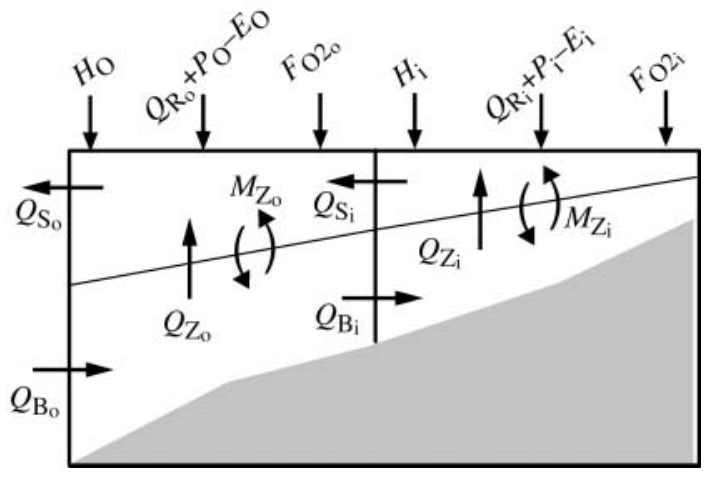

Fig. 2. Section across the main channel of the ría showing the study boxes (inner and outer) $\left(\overline{Q_{R}}\right.$, river discharge; $\bar{E}$, evaporation rate; $\bar{P}$, rainfall; $\bar{H}_{\text {r }}$ atmosphere-ocean heat exchange flux; $\bar{F}_{\mathrm{O}_{2}}$, atmospheric corrected oxygen flux; $\bar{Q}_{\mathrm{B}}$ and $\bar{Q}_{\mathrm{S}}$, bottom and surface horizontal fluxes at the open boundary; $\bar{Q}_{\mathrm{Z}}$ and $\bar{M}_{\mathrm{Z}}$, vertical advective and diffusive fluxes across the interface between the upper and lower layer of the study box). Subscripts ${ }_{i}$ and ${ }_{o}$ refer to the inner and outer boundary (and box), respectively

Fraga et al. 1992). $\overline{F_{\mathrm{O}_{2}}}$ is the average dissolved oxygen exchange with the atmosphere $\left(\mathrm{mmol} \mathrm{s}^{-1}\right)$. The average temperature, salinity, $\mathrm{NH}_{4}{ }^{+}, \mathrm{NO}_{2}{ }^{-}, \mathrm{NO}_{3}{ }^{-}$and $\mathrm{O}_{2 \mathrm{c}}$ of the surface and bottom layers of the open boundary and the box are obtained by numeric integration of measured profiles, considering the geometric characteristics of the estuary. $\overline{Q_{\mathrm{R}}}, \bar{P}, \overline{T_{\mathrm{A}}}$ and $\overline{T_{\mathrm{R}}}$ and the chemical composition of the river flow are known from direct measurements. Riverine $\mathrm{NH}_{4}{ }^{+}, \mathrm{NO}_{2}{ }^{-}$and $\mathrm{NO}_{3}{ }^{-}$levels are 15, 1 and $30 \mu \mathrm{M}$ N, respectively (Pérez et al. 1992). $\bar{H}$ and $\bar{F}_{\mathrm{O}_{2}}$ are estimated from measured variables (for further details, see Gilcoto et al. 2001).

Some reasonable assumptions are implicit in this system of equations. (1) The volume of the box is constant because a mean tidal volume is considered. (2) The average heat flux across the surface layer of the open boundary, $\overline{Q_{\mathrm{S}} \times T_{\mathrm{S}}}$, is simplified to be the product of $\overline{Q_{\mathrm{S}}} \times \overline{T_{\mathrm{S}}}$. The same is applicable to the bottom layer, and the river and precipitation fluxes. This is also valid for salinity, $\mathrm{NH}_{4}{ }^{+}, \mathrm{NO}_{2}{ }^{-}, \mathrm{NO}_{3}{ }^{-}$and $\mathrm{O}_{2 \mathrm{c}}$. The simplification is based on the extreme variability of waters fluxes compared with property changes in most estuarine and coastal systems. (3) The salinity of continental runoff and rainwater is set to zero. And (4) the produced/consumed organic matter has the average composition of marine phytoplankton, with $R_{\mathrm{N}}$ as the stoichiometric ratio of oxygen production (consumption) to total inorganic nitrogen consumption (production) during the synthesis (early degradation) of marine phytoplankton (=9.4 $\mathrm{mol} \mathrm{O}_{2} \mathrm{~mol} \mathrm{~N}^{-1}$; Anderson 1995).

Since there are more equations than unknowns, the solution that minimises the weighted sum of squared residuals of the 7 equations $\left(\sum_{\mathrm{i}=1}^{7} r_{\mathrm{i}}^{2} \times{w_{\mathrm{i}}}^{2}\right)$ must be retained. Here, $r_{\mathrm{i}}$ are the residuals of the volume $\left(r_{\mathrm{Q}}, \mathrm{m}^{3}\right.$ 
$\left.\mathrm{s}^{-1}\right)$, temperature $\left(r_{\mathrm{T}},{ }^{\circ} \mathrm{C} \mathrm{s}^{-1}\right)$, salt $\left(r_{\mathrm{S}}, \mathrm{kg} \mathrm{s}^{-1}\right)$ ammonium $\left(r_{\mathrm{NH}_{4^{\prime}}}\right.$ mmolN s$\left.{ }^{-1}\right)$, nitrite $\left(r_{\mathrm{NO}_{2}}, \mathrm{mmolN} \mathrm{s}^{-1}\right)$, nitrate $\left(r_{\mathrm{NO}_{3}}\right.$ mmol $\left.\mathrm{N} \mathrm{s}^{-1}\right)$ and $\mathrm{O}_{2 \mathrm{c}}\left(r_{\mathrm{O}_{2}}, \mathrm{mmolO}_{2} \mathrm{~s}^{-1}\right)$ budgets, partly caused by the simplifications above. The factors $W_{\mathrm{i}}(1)$ weight the conservation equations on the basis of the relative accuracy of every measured parameter and (2) normalize the residuals to a common dimension $\left(\mathrm{m}^{3} \mathrm{~s}^{-1}\right)$. The corresponding factor for the heat budget is:

$$
w_{\mathrm{T}}=\frac{\left|T_{\mathrm{B}}-T_{\mathrm{S}}\right|}{\varepsilon_{\mathrm{T}}} \times\left(\sum_{j=1}^{n}\left(T_{\mathrm{B}}-T_{\mathrm{S}}\right)_{j}^{2} / n\right)^{-1 / 2}=\frac{\left|T_{\mathrm{B}}-T_{\mathrm{S}}\right|}{\varepsilon_{\mathrm{T}}} \times \xi_{\mathrm{T}}^{-1}
$$

The weighting term $\left|T_{\mathrm{B}}-T_{\mathrm{S}}\right| / \varepsilon_{\mathrm{T}}$ indicates the number of times that the temperature gradient at the open boundary exceeds the accuracy of the determination of temperature. The normalizing term

$$
\left(\sum_{j=1}^{n}\left(T_{\mathrm{B}}-T_{\mathrm{S}}\right)_{j}^{2} / n\right)^{1 / 2}
$$

is the square root of the squared temperature gradient at the study site open-boundary averaged over the whole set of time intervals considered (n). Equivalent normalizing/weighting terms can be written for salinity, $\mathrm{NH}_{4}{ }^{+}, \mathrm{NO}_{2}^{-}, \mathrm{NO}_{3}{ }^{-}$and $\mathrm{O}_{2 \mathrm{c}}$. Finally, a large value of the factor for the volume budget $\left(w_{\mathrm{Q}}>\right.$ tidal prism volume) is preferred to satisfy the desirable condition that the volume is accurately conserved $\left(r_{\mathrm{Q}}=0\right)$.

Once optimum $\overline{Q_{\mathrm{S}}}$ and $\overline{Q_{\mathrm{B}}}$ are known a new system of 7 linear equations (volume, heat, salt, ammonium, nitrite, nitrate and corrected oxygen conservation) with 5 unknowns $\left(\bar{Q}_{\mathrm{Z}}, \bar{M}_{\mathrm{Z}},{\overline{\rho \mathrm{NH}_{4 \mathrm{~L}}}}_{\overline{\rho \mathrm{NO}_{2 \mathrm{~L}}}}\right.$ and ${\overline{\rho \mathrm{NO}_{3 \mathrm{~L}}}}_{\mathrm{L}})$ can be written for the lower layer of the box:

$$
\begin{aligned}
& \bar{Q}_{\mathrm{Z}}-\bar{Q}_{\mathrm{B}}+\frac{\Delta V_{\mathrm{L}}}{\Delta t}=0+r_{\mathrm{Q}_{\mathrm{L}}} \\
& \bar{Q}_{\mathrm{Z}} \times \bar{T}_{\mathrm{Z}}-\bar{Q}_{\mathrm{B}} \times \bar{T}_{\mathrm{B}}-\bar{M}_{\mathrm{Z}} \times\left(\bar{T}_{\mathrm{U}}-\bar{T}_{\mathrm{L}}\right) \\
& +\bar{V}_{\mathrm{L}} \times \frac{\Delta T_{\mathrm{L}}}{\Delta t}+\bar{T}_{\mathrm{L}} \times \frac{\Delta V_{\mathrm{L}}}{\Delta t}=0+r_{\mathrm{T}_{\mathrm{L}}} \\
& \bar{Q}_{\mathrm{Z}} \times \bar{S}_{\mathrm{Z}}-\bar{Q}_{\mathrm{B}} \times \bar{S}_{\mathrm{B}}-\bar{M}_{\mathrm{Z}} \times\left(\bar{S}_{\mathrm{U}}-\bar{S}_{\mathrm{L}}\right) \\
& +\bar{V}_{\mathrm{L}} \times \frac{\Delta S_{\mathrm{L}}}{\Delta t}+\bar{S}_{\mathrm{L}} \times \frac{\Delta V_{\mathrm{L}}}{\Delta t}=0+r_{\mathrm{S}_{\mathrm{L}}} \\
& \bar{Q}_{\mathrm{Z}} \times \overline{\mathrm{NH}}_{4 \mathrm{Z}}-\bar{Q}_{\mathrm{B}} \times \overline{\mathrm{NH}}_{4 \mathrm{~B}}-\bar{M}_{\mathrm{Z}} \times\left(\overline{\mathrm{NH}}_{4 \mathrm{U}}-\overline{\mathrm{NH}}_{4 \mathrm{~L}}\right) \\
& -\overline{\rho \mathrm{NH}_{4 \mathrm{~L}}}+\bar{V}_{\mathrm{L}} \times \frac{\bar{\Delta}_{\mathrm{NH}}^{4 \mathrm{~L}}}{\Delta t}+\overline{\mathrm{N}}_{4 \mathrm{~L}} \times \frac{\Delta V_{\mathrm{L}}}{\Delta t}=0+r_{\mathrm{NH}_{4 \mathrm{~L}}} \\
& \bar{Q}_{\mathrm{Z}} \times \overline{\mathrm{NO}}_{2 \mathrm{Z}}-\bar{Q}_{\mathrm{B}} \times \overline{\mathrm{NO}}_{2 \mathrm{~B}}-\bar{M}_{\mathrm{Z}} \times\left(\overline{\mathrm{NO}}_{2 \mathrm{U}}-\overline{\mathrm{NO}}_{2 \mathrm{~L}}\right) \\
& -\overline{\rho \mathrm{NO}_{2 \mathrm{~L}}}+\bar{V}_{\mathrm{L}} \times \frac{\overline{\Delta \mathrm{NO}_{2 \mathrm{~L}}}}{\Delta t}+\overline{\mathrm{NO}}_{2 \mathrm{~L}} \times \frac{\Delta V_{\mathrm{L}}}{\Delta t}=0+r_{\mathrm{NO}_{2 \mathrm{~L}}} \\
& \bar{Q}_{\mathrm{Z}} \times \overline{\mathrm{NO}}_{3 \mathrm{Z}}-\bar{Q}_{\mathrm{B}} \times \overline{\mathrm{NO}}_{3 \mathrm{~B}}-\bar{M}_{\mathrm{Z}} \times\left(\overline{\mathrm{NO}}_{3 \mathrm{U}}-\overline{\mathrm{NO}}_{3 \mathrm{~L}}\right) \\
& -\overline{\rho_{N O_{3 L}}}+\bar{V}_{\mathrm{L}} \times \frac{\overline{\Delta \mathrm{NO}_{3 \mathrm{~L}}}}{\Delta t}+\overline{\mathrm{NO}}_{3 \mathrm{~L}} \times \frac{\Delta V_{\mathrm{L}}}{\Delta t}=0+r_{\mathrm{NO}_{3 \mathrm{~L}}}
\end{aligned}
$$

$$
\begin{aligned}
& \bar{Q}_{\mathrm{Z}} \times \overline{\mathrm{O}}_{2 \mathrm{cZ}}-\bar{Q}_{\mathrm{B}} \times \overline{\mathrm{O}}_{2 \mathrm{cB}}-\bar{M}_{\mathrm{Z}} \times\left(\overline{\mathrm{O}}_{2 \mathrm{cU}}-\overline{\mathrm{O}}_{2 \mathrm{cL}}\right) \\
& +R_{N} \times\left(\overline{\rho \mathrm{NH}_{4 \mathrm{~L}}}+\overline{\rho \mathrm{NO}_{2 \mathrm{~L}}}+\overline{\rho \mathrm{NO}_{3 \mathrm{~L}}}\right)
\end{aligned}
$$

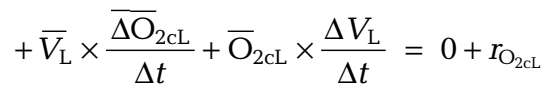

where $\bar{Q}_{\mathrm{Z}}$ is the average advective flux from the lower to the upper layer of the box $\left(\mathrm{m}^{3} \mathrm{~s}^{-1}\right), V_{\mathrm{L}}$ is the volume of the lower layer of the box $\left(\mathrm{m}^{3}\right) ; r_{\mathrm{QL}}$ is the residual of the volume budget for the lower layer $\left({ }^{\circ} \mathrm{C} \mathrm{m}^{3} \mathrm{~s}^{-1}\right), \bar{M}_{\mathrm{Z}}$ is the average turbulent mixing between the upper and lower layer of the study volume $\left(\mathrm{m}^{3} \mathrm{~s}^{-1}\right), \bar{T}_{\mathrm{Z}}$ is the average temperature at the interface between the upper and lower layer of the box $\left({ }^{\circ} \mathrm{C}\right), \bar{T}_{\mathrm{L}}$ and $\bar{T}_{\mathrm{U}}$ are the average temperatures in the lower and upper layer of the box $\left({ }^{\circ} \mathrm{C}\right), \bar{V}_{\mathrm{L}} \times\left(\Delta T_{\mathrm{L}} / \Delta t\right)$ is the change of heat content of the lower layer of the box between 2 consecutive surveys due to the change in the average temperature of that layer $\left({ }^{\circ} \mathrm{C} \mathrm{m}-3 \mathrm{~s}^{-1}\right), \overline{T_{\mathrm{L}}} \times\left(\Delta V_{\mathrm{L}} / \Delta t\right)$ is the change of heat content of the lower layer of the box due to the change in the volume of the lower layer $\left({ }^{\circ} \mathrm{C} \mathrm{m}-3 \mathrm{~s}^{-1}\right)$ and $\overline{\rho N H}_{4 \mathrm{~L}}$ is the net ecosystem production of ammonium in the lower layer of the box $\left(\mathrm{mmol} \mathrm{s}^{-1}\right)$. In the case of the $\mathrm{NO}_{2}{ }^{-}, \mathrm{NO}_{3}{ }^{-}$and $\mathrm{O}_{2 \mathrm{c}}$ conservation equations, the meaning of the corresponding variables is the same as for volume, heat, salt and ammonium.

For the upper layer, $\overline{\rho N H}_{4 \mathrm{U}}=\overline{\rho N H}_{4}-\overline{\rho N H}_{4 \mathrm{~L}}$, $\overline{\rho N O}_{2 \mathrm{U}}=\overline{\rho N O}_{2}-\overline{\rho N O}_{2 \mathrm{~L}}$ and $\overline{\rho N O}_{3 \mathrm{U}}=\overline{\rho N O}_{3}-\overline{\rho N O}_{3 \mathrm{~L}}$. Finally, $K_{\text {org }}$ (rate of conversion of $\mathrm{N}_{\text {org }}$ into $\mathrm{NH}_{4}^{+}$), $K_{1}$ (rate of conversion of $\mathrm{NH}_{4}{ }^{+}$into $\mathrm{NO}_{2}^{-}$) and $K_{2}$ (rate of conversion of $\mathrm{NO}_{2}^{-}$into $\mathrm{NO}_{3}^{-}$) can be estimated as:

$$
\begin{gathered}
K_{\text {org }}=\overline{\rho \mathrm{NH}}_{4}+\overline{\rho \mathrm{NO}}_{2}+\overline{\rho \mathrm{NO}}_{3} \\
K_{1}=\overline{\rho \mathrm{NO}}_{2}+\overline{\rho \mathrm{NO}}_{3} \\
K_{2}=\overline{\rho \mathrm{NO}}_{3}
\end{gathered}
$$

Robustness of the estimation. The robustness of the estimations of $\bar{Q}_{\mathrm{S}}, \bar{Q}_{\mathrm{B}}, \bar{Q}_{\mathrm{Z}}, \bar{M}_{\mathrm{Z}}, \overline{\rho N H}_{4}, \overline{\rho N O}_{2}, \overline{\rho N O}_{3}$, $\overline{\rho N H}_{4 \mathrm{~L}}, \overline{\rho N O}_{2 \mathrm{~L}}, \overline{\rho \mathrm{NO}}_{3 \mathrm{~L}}, \overline{\rho N H}_{4 \mathrm{U}},{\overline{\rho N H_{2 U}}}_{2}$ and $\overline{\rho N O}_{3 \mathrm{U}}$ have been approached following the procedure of Maamaatuaiahutapu et al. (1992) for the optimum multiparameter analysis of water mass composition. A number of perturbed systems of mass balance equations (Eqs. 4 to 10,12 to 18,19 to 21 ) can be obtained by random modification of the measured variables within the limits of the oceanographic error of their estimations. It is expected that the errors associated with the sampling strategy, i.e. the criteria to choose certain numbers of sampling stations and depths that should be representative of the whole study system, are much larger than the analytical errors. Therefore, a representativeness error (the 'oceanographic error') should be estimated. As Gilcoto et al. (2001) did in a previous study of the Ría de Vigo, we considered a relative error of $10 \%$ as the representativeness error for local wind, 
air temperature, relative humidity and atmospheric partial pressure of oxygen, which are involved in the parameterizations of the land-sea and air-sea exchange fluxes (fresh water flow, evaporation, heat and $\mathrm{O}_{2}$ ). For the chemical variables (salinity, temperature, $\mathrm{O}_{2}, \mathrm{NH}_{4}{ }^{+}, \mathrm{NO}_{2}^{-}$and $\mathrm{NO}_{3}{ }^{-}$), a relative error of the vertical gradients $(20 \%)$ has been chosen as the representativeness error. A total of 250 perturbed systems of equations can be produced, and 250 different optimum solutions can be obtained. The average of the 250 solutions will be the value of the estimation, and the standard deviation of the 250 solutions will be the estimated error.

Appendices 1 and 2 summarize the outputs of the inverse method on the circulation and the $\mathrm{N}$ dynamics of the ría, respectively. Examination of the errors involved in the estimations indicates that the sensitivity of the method is about $\pm 0.5 \mathrm{~km} \mathrm{~d}^{-1}$ for the horizontal velocities, $\pm 0.5 \mathrm{~m} \mathrm{~d}^{-1}$ for the vertical advective and mixing velocities and $\pm 0.2 \mu \mathrm{M} \mathrm{d}^{-1}$ for the net ammonification and nitrification rates. Although these threshold values are higher than those provided by direct measurements, they have the advantage of their validity at the ecosystem level.

The proposed model portrays a simplistic scenario of $\mathrm{N}$ dynamics, ignoring potentially important processes such as denitrification or $\mathrm{N}_{2}$ fixation. On the one hand, $\mathrm{N}_{2}$ fixation is relevant only in the inner reaches of the Ría de Vigo, within San Simon Bay, a water parcel not sampled during the field work. On the other hand, the flushing rates of the Ría de Vigo ( $<1 \mathrm{wk})$, enhanced by upwelling/downwelling processes, ensure that this embayment is permanently well-ventilated. Therefore, denitrification is prevented in the water column. Although it has never been measured, denitrification is probably a significant process in the sediments of the ría. Unfortunately, our inverse method does not differentiate between processes in the water column and the sediments. For this reason, the sediments are considered part of the lower layer of the ría. What is the impact of benthic denitrification processes on the nitrogen dynamics of the lower water column? To answer this question, the system of mass balance equations (Eqs. 4 to 10), can be solved by removing Eq. (10), i.e. the equation that assumes that: (a) only ammonification and nitrification are relevant and (b) the composition of the organic material that is preferentially degraded is Redfieldian $\left(R_{\mathrm{N}}=-9.4\right)$. The results of this test produced no significant differences between the original results considering the complete set of equations and the new results removing the $\mathrm{O}_{2}$ mass balance equation. Therefore, it proves that our simple model is appropriate to solve the nitrogen dynamics of the rías at the space $\left(\sim 1 \mathrm{~km}^{3}\right)$ and time $(\sim 1 / 2 \mathrm{wk})$ scales involved.

\section{RESULTS \\ Hydrographic conditions in the Ría de Vigo during September 1990 and 1991}

\author{
September 1990
}

The time evolution of temperature in the middle ría is the best indicator of the short-time scale variability of the hydrographic conditions in the Rías Baixas during late summer to early winter, when solar irradiation is high and continental runoff is usually scarce (Nogueira et al. 1997). Fig. 3a shows a complete cycle of vigorous coastal upwelling of ENACW (eastern North Atlantic control waters) $\left(<14^{\circ} \mathrm{C}\right)$ from 14 to 20 September, followed by a pronounced downwelling event from 20 to 27 September, when the ENACW was replaced by warm $\left(>17^{\circ} \mathrm{C}\right)$ shelf surface waters. The average temperature profile along the main axis of the ría from 14 to 27 September (Fig. 3b) indicated that (1) downwelling was the dominant process during the study period, as follows from the downward slope of the isotherms towards the coast, and (2) the vigor of the upwelling-downwelling cycle did not allow strong water column stratification: the temperature gradient was $<3.5^{\circ} \mathrm{C}$.

Bottom velocities in the middle ría were on the order of $2 \mathrm{~km} \mathrm{~d}^{-1}$ (inwards) from 14 to 20 September and $-2 \mathrm{~km} \mathrm{~d}^{-1}$ (outwards) from 20 to 27 September (Fig. 3c). Regarding vertical mixing, $\bar{v}_{\mathrm{M}}$ remained low $(<0.3 \mathrm{~m}$ $\left.\mathrm{d}^{-1}\right)$, except from 18 to 20 September, when it was $0.6 \mathrm{~m} \mathrm{~d}^{-1}$. For comparison, $\bar{v}_{\mathrm{Z}}$ was about 3 -fold $\bar{v}_{\mathrm{M}}$ from 18 to 20 September 1990 . The average residual circulation of the inner and outer Ría de Vigo (Fig. 1) from 14 to 27 September (Fig. 3d) yielded reduced horizontal $\left(<0.3 \mathrm{~km} \mathrm{~d}^{-1}\right)$ and vertical $\left(<0.1 \mathrm{~m} \mathrm{~d}^{-1}\right)$ velocities as a consequence of compensation of strong upwelling from 14 to 20 September with strong downwelling from 20 to 27 September (Fig. 3a,b). Vertical mixing was reduced $\left(<0.8 \mathrm{~m} \mathrm{~d}^{-1}\right)$.

\section{September 1991}

The time evolution of temperature at Stn 3 (Fig. 3e) showed a brief downwelling event from 9 to 13 September and moderate but sustained upwelling from 13 to 26 September. As a consequence, the average temperature profile along the main axis of the ría (Fig. 3f) indicated the dominance of upwelling (compare the $15^{\circ} \mathrm{C}$ isolines of Fig. 3b,f) and a marked stratification of the water column: the temperature gradient was $>5.5^{\circ} \mathrm{C}$.

Bottom velocities in the middle ría during September 1991 indicate an outgoing velocity of $0.7 \mathrm{~m} \mathrm{~d}^{-1}$ from 9 to 13 September, a strong ingoing velocity of $3.1 \mathrm{~km} \mathrm{~d}^{-1}$ 


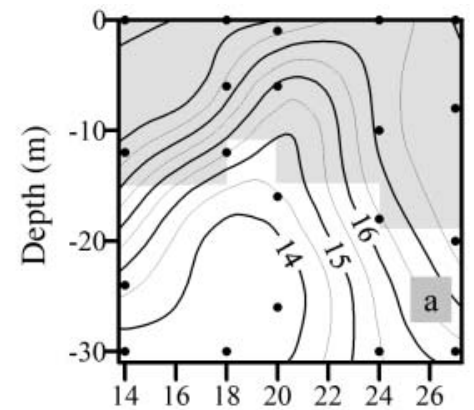

Day in September 1990

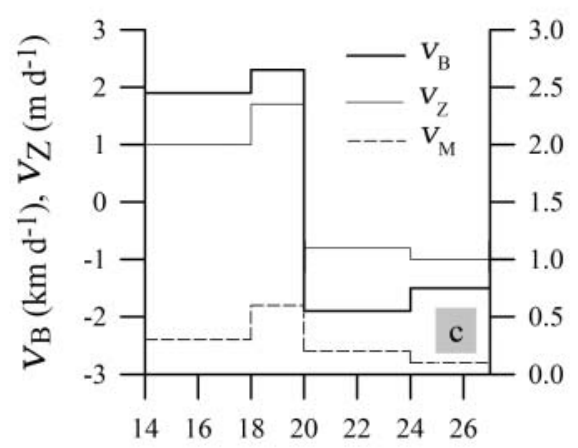

Day in September 1990

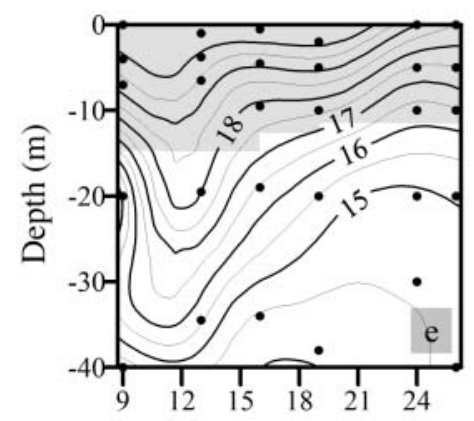

Day in September 1991

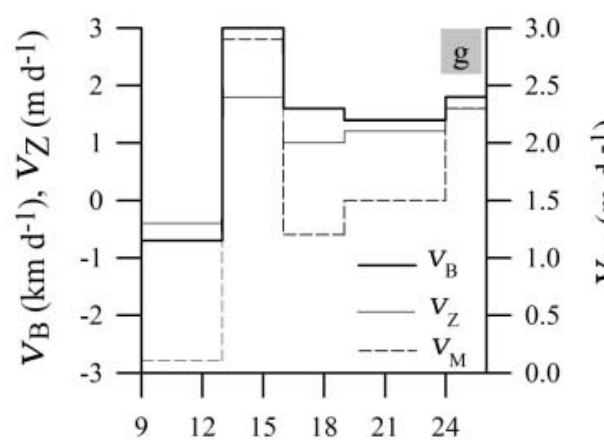

Day in September 1991

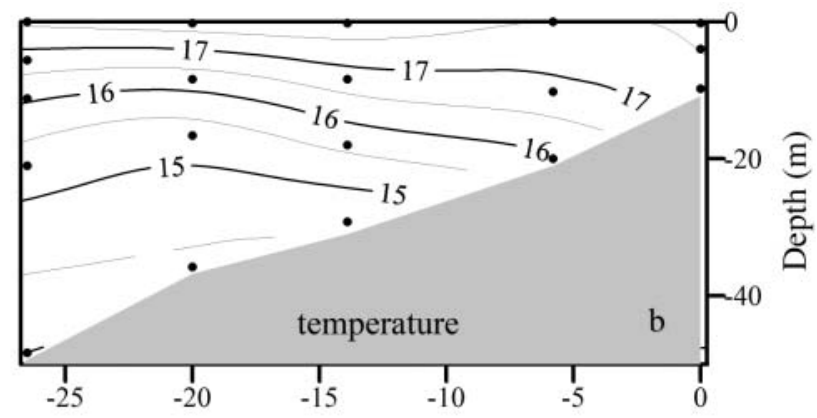

Distance (km)
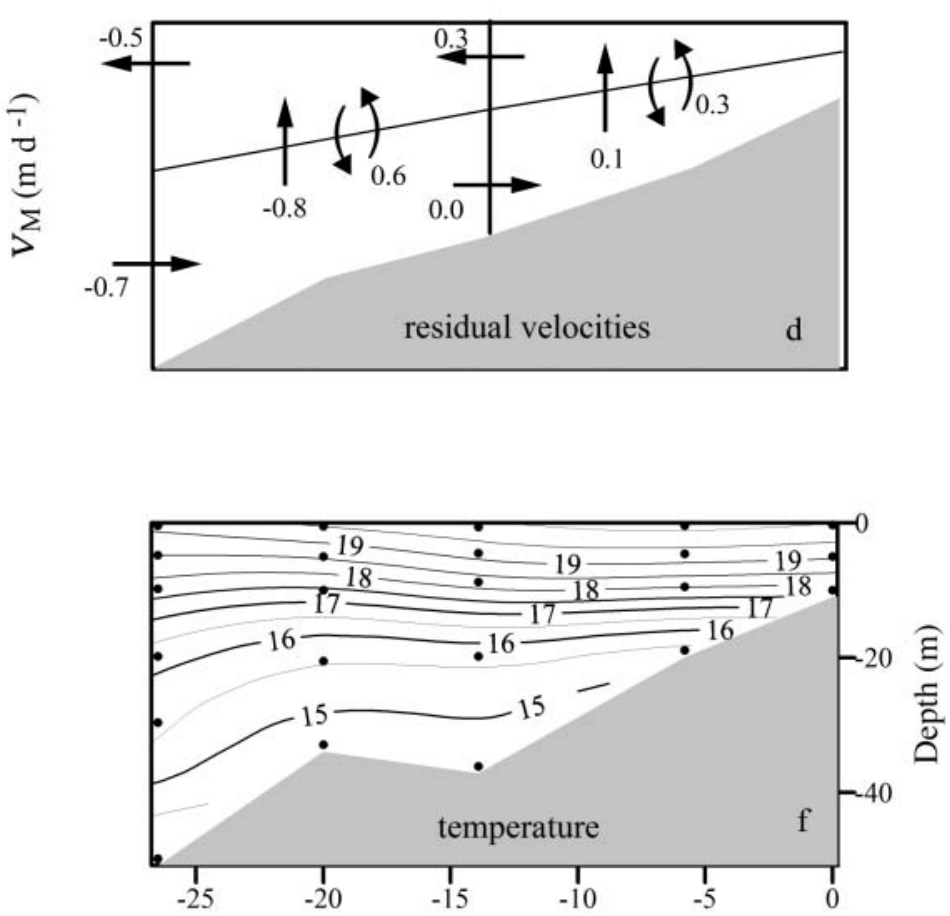

Distance (km)

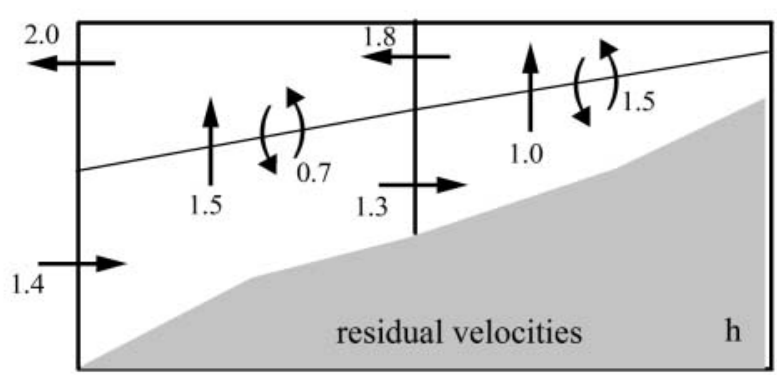

Fig. 3. (a) Time course of temperature and (c) $\bar{V}_{\mathrm{B}}, \bar{V}_{\mathrm{Z}}$ and $\bar{V}_{\mathrm{M}}$ during September 1990, (e) temperature and (g) $\bar{V}_{\mathrm{B}}, \bar{V}_{\mathrm{Z}}$ and $\bar{V}_{\mathrm{M}}$ during September 1991 at Stn 3. (b) Average temperature and (d) $\bar{V}_{\mathrm{B}}, \bar{V}_{\mathrm{S}}, \bar{V}_{\mathrm{Z}}$ and $\bar{V}_{\mathrm{M}}$ during September 1990, (f) temperature and (h) $\bar{V}_{\mathrm{B}}$, $\bar{V}_{\mathrm{S}}, \bar{V}_{\mathrm{Z}}$ and $\bar{V}_{\mathrm{M}}$ during September 1991 along the central axis of the Ría de Vigo (temperature in ${ }^{\circ} \mathrm{C}_{i} \bar{V}_{\mathrm{B}}$ and $\bar{V}_{\mathrm{S}}$ in $\mathrm{km} \mathrm{d}{ }^{-1}, \bar{v}_{\mathrm{Z}}$ and $\bar{V}_{\mathrm{M}}$ in $\mathrm{m} \mathrm{d}^{-1}$ ). Positive values are in arrow direction and negative values are contrary to arrow direction in panels (d) and (h). Shaded areas in panels (a) and (e) represent the upper layer 
from 13 to 16 September and a sustained ingoing velocity of $\sim 1.5 \mathrm{~km} \mathrm{~d}^{-1}$ from 19 to 26 September (Fig. 3g). In parallel, upward velocities of $\bar{v}_{Z}>1 \mathrm{~m} \mathrm{~d}^{-1}$ were computed for the period from 13 to 26 September. The dominance of upwelling during this period is clearly reflected in the average velocity fields (Fig. 3h), with surface horizontal velocities of $\sim 2 \mathrm{~km} \mathrm{~d}^{-1}$ either in the inner or outer ría. Average vertical velocities of 1.0 and $1.5 \mathrm{~m} \mathrm{~d}^{-1}$ in the inner and outer ría, respectively, were also a consequence of coastal upwelling. Regarding $\bar{v}_{\mathrm{M}}$, it remained very low from 9 to 13 September $\left(0.1 \mathrm{~m} \mathrm{~d}^{-1}\right)$ and increased sharply from 13 to 16 September $(2.9 \mathrm{~m}$ $\mathrm{d}^{-1}$ ). On average, the $\bar{v}_{Z}$ was $2 / 3$ of $\bar{v}_{M}$ during the period from 9 to 26 September in the inner box.

\section{$\mathrm{N}$-nutrient distributions in the Ría de Vigo during September 1990 and 1991}

\section{September 1990}

Comparison of temperature (Fig. 3a,b) and Nnutrient profiles (Fig. $4 \mathrm{a}-\mathrm{f}$ ) shows that the temporal and spatial distributions of nitrate are very well correlated with temperature $(r=-0.84, n=108, \mathrm{p}<0.001)$, as expected from the high nutrient levels of upwelled ENACW $(>6 \mu \mathrm{M} \mathrm{N})$ and the low levels of shelf surface waters $(<0.5 \mu \mathrm{M} \mathrm{N})$ that exchanges within the rías (Álvarez-Salgado et al. 1993, 1996, Nogueira et al. 1997). Nitrite profiles also correlate with temperature $(r=-0.77, \mathrm{n}=108, \mathrm{p}<0.001)$, suggesting that most of the nitrite in the ría is transported from the shelf by the upwelled ENACW as is also the case for nitrate. In any case, nitrite is not a quantitatively relevant $\mathrm{N}$-nutrient form in the ría, with levels always $<0.7 \mu \mathrm{M} N$. Finally, ammonium distributions cannot be explained by temperature $(r=-0.20, \mathrm{n}=108, \mathrm{p}<0.05)$, indicating that they are the result of intense nitrogen regeneration processes occurring within the ría.

\section{September 1991}

N-nutrient distributions during September 1991 contrasted with the distributions during September 1990. Despite that bottom temperatures were of the same order during both periods $\left(14\right.$ to $\left.15^{\circ} \mathrm{C}\right)$, nitrate levels doubled during September 1991 (Fig. 5e) compared to September 1990 (Fig. 4e) in the middle ría. The same is applicable to the average distributions along the main axis of the ría (Figs. 4f, 5f). In addition, nitrite levels during September 1991 were higher than during September 1990: $>1 \mu \mathrm{M} \mathrm{N}$ compared with $<0.7 \mu \mathrm{M} \mathrm{N}$. The highest nitrite levels were observed in the bottom middle ría (Fig. 5d). The correlations of nitrate with tem- perature $(r=-0.87, n=184, \mathrm{p}<0.001)$ and nitrite with temperature $(r=-0.61, n=184, \mathrm{p}<0.01)$ are high, as during September 1990. However, ammonium does not correlate significantly with temperature $(r=-0.37$, $n=184, \mathrm{p}<0.05)$, and, although a subsurface maximum with $>4 \mu \mathrm{M} \mathrm{N}$ developed in the middle ría (Fig. 5a), when average concentrations from 9 to 26 September are considered (Fig. 5b), the site of maximum ammonium levels is found again in the inner bottom ría.

\section{Ammonification and nitrification in the Ría de Vigo during September 1990 and 1991}

Application of the inverse method described in the 'Materials and methods' section to the thermohaline and chemical distributions described in the previous paragraphs allows quantification of ammonification and nitrification processes. It is important to note that rates presented in Figs. $4 \& 5$ and Appendix 2 (in $\mu \mathrm{M} \mathrm{N} \mathrm{d}^{-1}$ ) are based on the volume of the entire inner and outer boxes to facilitate the comparison between the upper and lower layers. To obtain rates based on upper and lower layer volumes, the numbers should be multiplied by $1.7 \pm 0.2$ and $2.2 \pm 0.4$ for the inner box and by $2.4 \pm 0.4$ and $1.9 \pm 0.3$ for the outer box, respectively.

\section{September 1990}

Low, but highly variable, ammonification rates $\left(K_{\text {org }}\right)$ were inferred for the lower layer of the inner segment of the ría (Fig. 4g), increasing from $-0.1 \pm 0.1 \mu \mathrm{M} \mathrm{N} \mathrm{d}^{-1}$ on 14 to 18 September to $0.3 \pm 0.1 \mu \mathrm{M} \mathrm{N} \mathrm{d}^{-1}$ on $24-27$ September. In the upper layer, ammonification dominated during upwelling from 14 to 18 September $\left(K_{\text {org }}=0.4 \pm 0.1 \mu \mathrm{MN} \mathrm{d}^{-1}\right)$, whereas nitrogen assimilation occured during the 20 to 24 September upwelling relaxation $\left(K_{\text {org }}=-0.8 \pm 0.1 \mu \mathrm{MN} \mathrm{d}^{-1}\right) . K_{\text {org }}$ values in the upper and lower layers do not covary. Average rates for the upper and lower layers during the period from 14 to 27 September (Fig. $4 \mathrm{~h}$ ) indicated that only $0.1-0.2 \mu \mathrm{MN} \mathrm{d}^{-1}$ of the organic nitrogen was mineralized to ammonium in the lower layer of either the inner or the outer box, about half of which was oxidized to nitrate in the outer box. Average N-nutrient assimilation in the upper layer of the inner ría was also very low during this period $\left(0.16 \mu \mathrm{M} \mathrm{N} \mathrm{d}^{-1}\right)$, with nitrate being the most relevant $\mathrm{N}$-nutrient source: $75 \%$ on average over the period from 14 to 27 September. In the upper layer of the outer ría, $\mathrm{N}$-nutrient assimilation was of the same order $\left(0.12 \mu \mathrm{M} \mathrm{N} \mathrm{d}^{-1}\right), 3 / 4$ was supported by nitrate and $1 / 4$ by ammonium. 

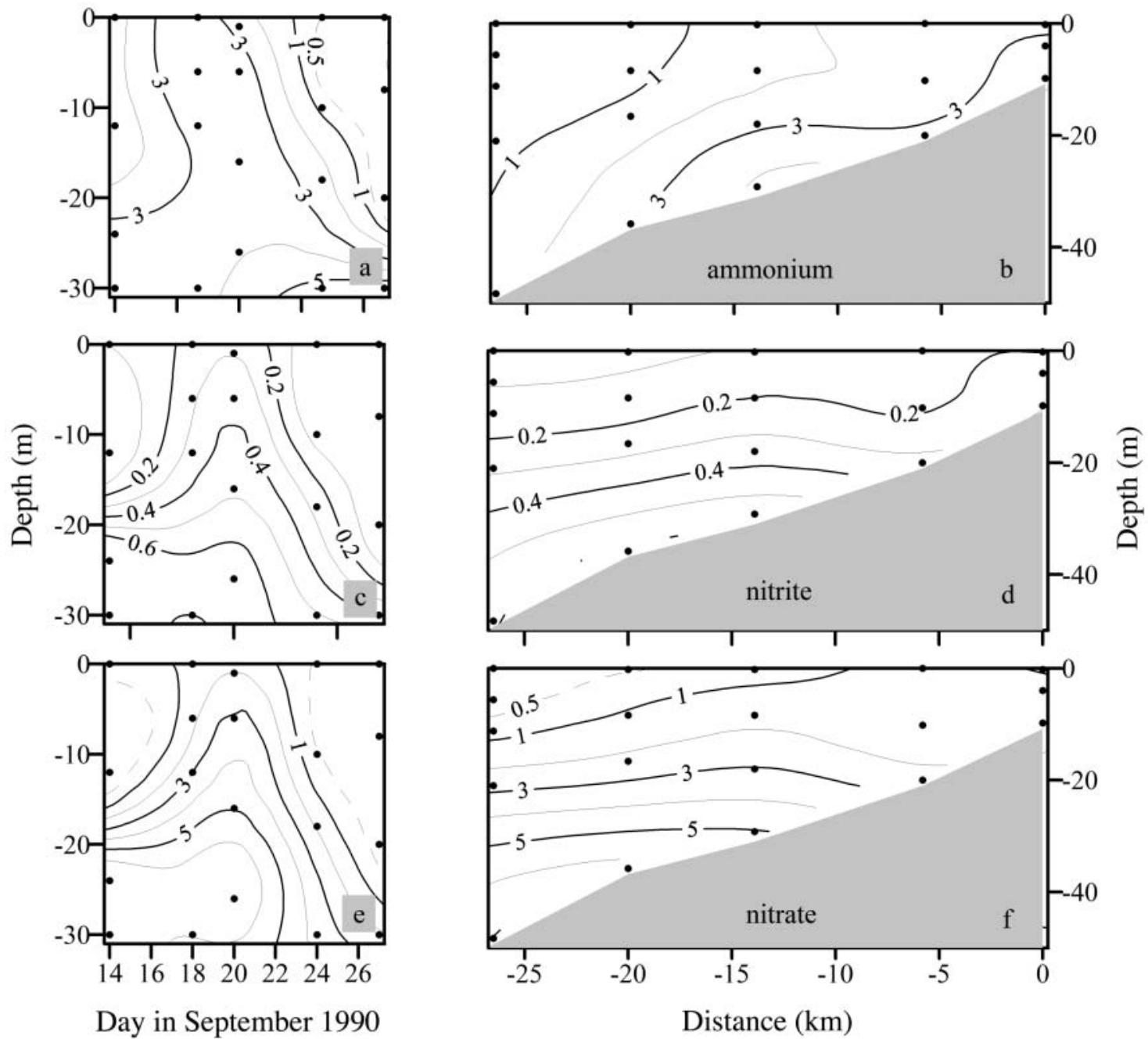

Day in September 1990
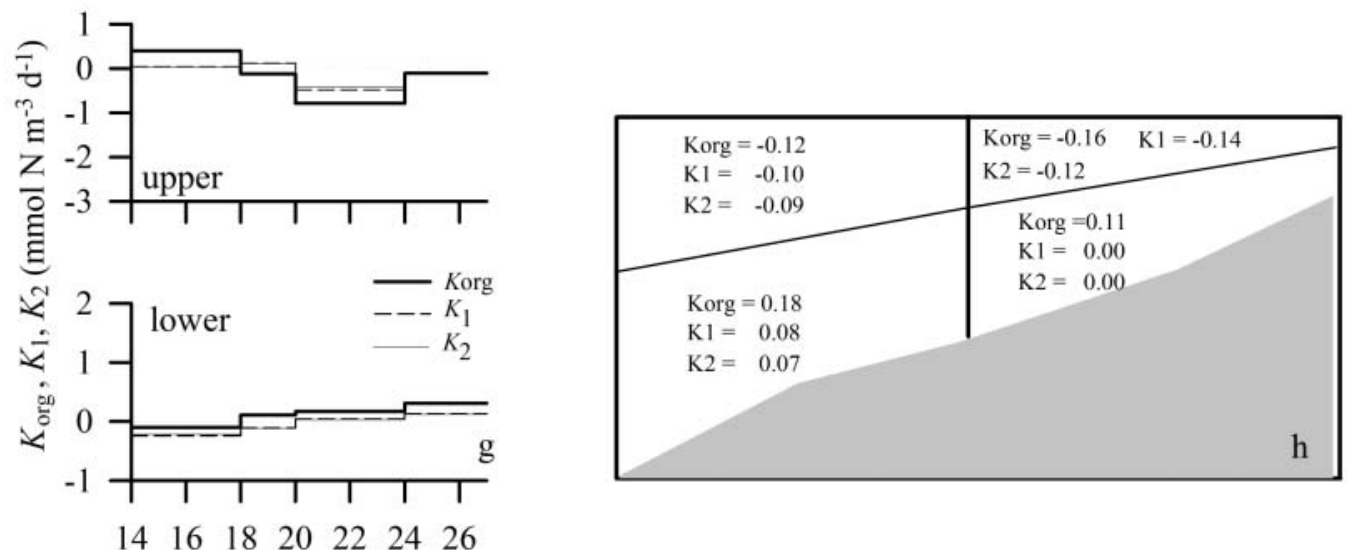

\section{Day in September 1990}

Fig. 4. (a) Time course of ammonium, (c) nitrite and (e) nitrate profiles at Stn 3. (g) $K_{\mathrm{org}}, K_{1}$ and $K_{2}$ profiles in the inner segment of the ría. (b) Average ammonium, (d) nitrite, (f) nitrate and (h) $K_{\text {org }} K_{1}$ and $K_{2}$ profiles along the central axis of the Ría de Vigo during September 1990. N-nutrients in $\mu \mathrm{M} \mathrm{N}$ and $K_{\text {org }}, K_{1}$ and $K_{2}$ in $\mu \mathrm{M} \mathrm{N} \mathrm{d}^{-1} . K_{\text {org }}, K_{1}$ and $K_{2}$ are based on the volume of the entire inner and outer boxes to facilitate comparison between the upper and lower layers. To obtain rates based on upper and lower layer volumes, these numbers should be multiplied by $1.7 \pm 0.2$ and $2.2 \pm 0.4$ for the inner box and by $2.4 \pm 0.4$ and $1.9 \pm 0.3$ for the outer box, respectively 


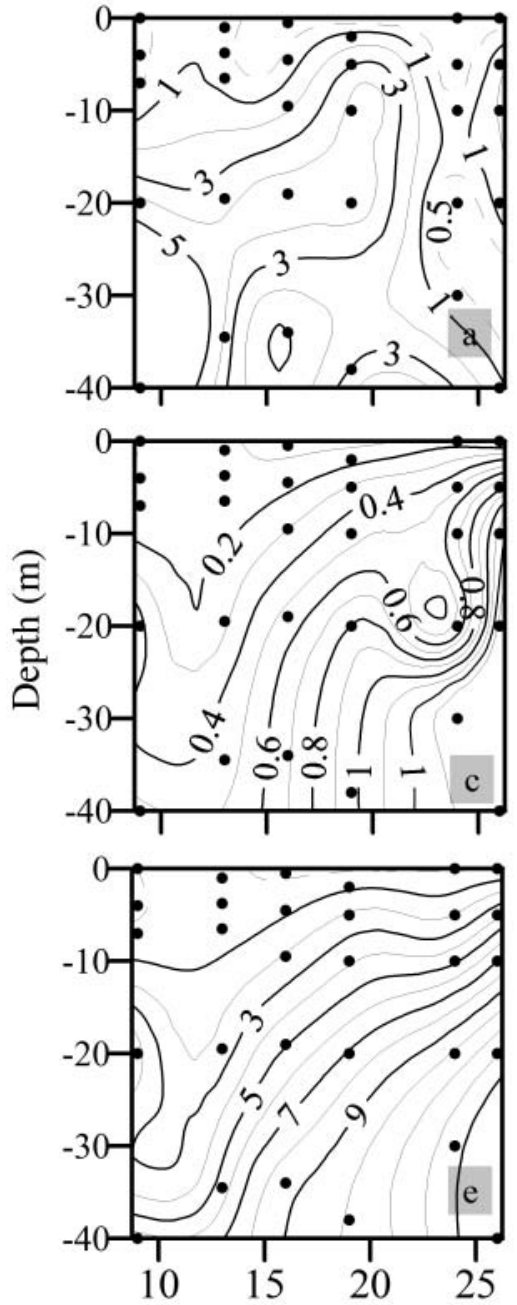

Day in September 1991

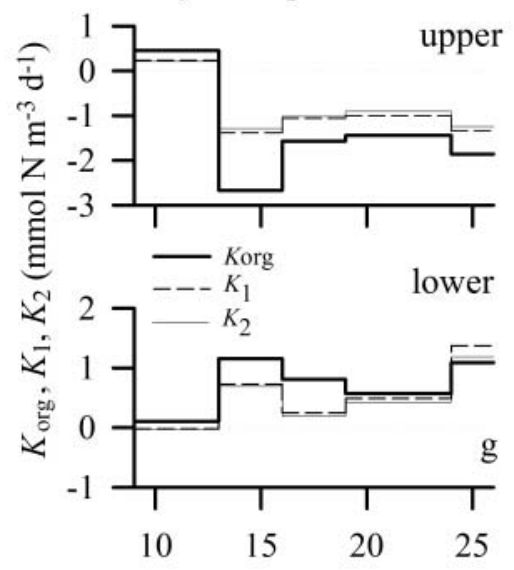

Day in September 1991
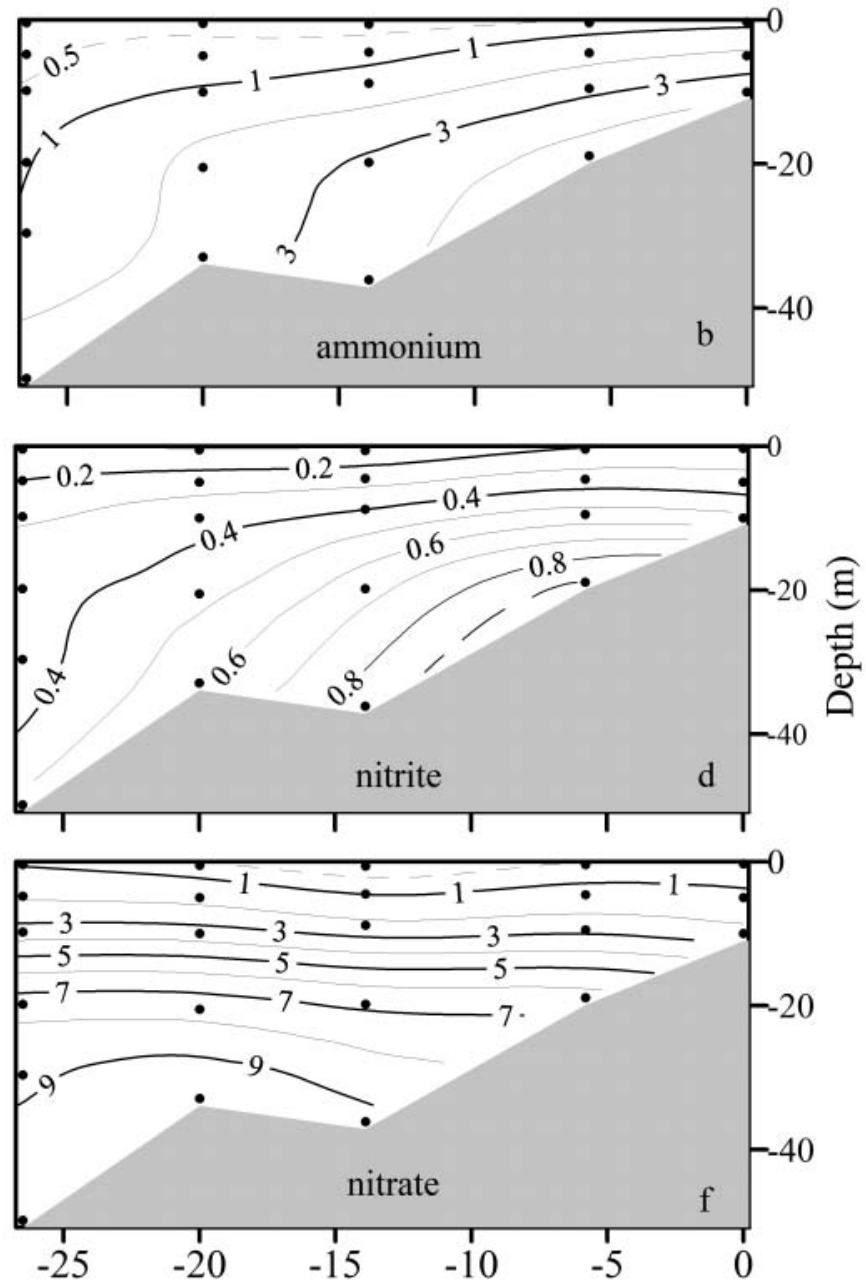

Distance $(\mathrm{km})$

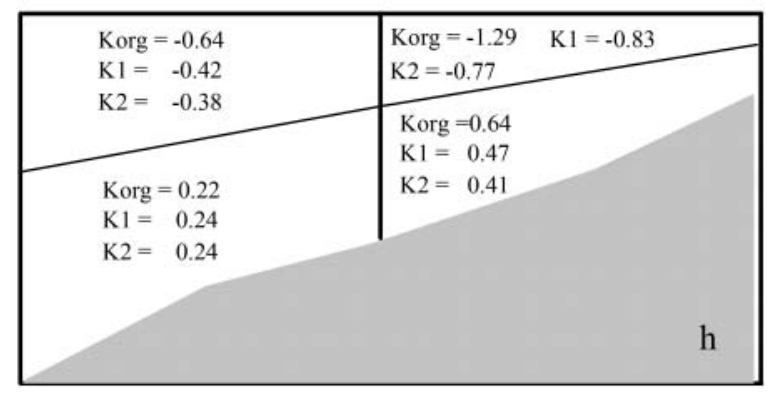

Fig. 5. (a) Time course of ammonium, (c) nitrite and (e) nitrate profiles at Stn 3. (g) $K_{\text {org }}, K_{1}$ and $K_{2}$ profiles in the inner segment of the ría. (b) Average ammonium, (d) nitrite, (f) nitrate and (h) $K_{\text {org, }} K_{1}$ and $K_{2}$ profiles along the central axis of the Ría de Vigo during September 1991 ( $\mathrm{N}$-nutrients in $\mu \mathrm{M} \mathrm{N}$ and $K_{\text {org }}, K_{1}$ and $K_{2}$ in $\mu \mathrm{M} \mathrm{N} \mathrm{d}^{-1}$ ). $K_{\text {org }}, K_{1}$ and $K_{2}$ are based on the volume of the entire inner and outer boxes to facilitate the comparison between the upper and lower layers. To obtain rates based on upper and lower layer volumes, these numbers should be multiplied by $1.7 \pm 0.2$ and $2.2 \pm 0.4$ for the inner box and by $2.4 \pm 0.4$ and $1.9 \pm 0.3$ for the outer box, respectively 
September 1991

Compared with September 1990, biogeochemical processes have much more influence on N-nutrient distribution during September 1991. Ammonification in the lower layer of the inner box (Fig. $5 \mathrm{~g}$ ) ranged from $0.1 \pm 0.1$ to $1.2 \pm 0.3 \mu \mathrm{M} \mathrm{N} \mathrm{d}^{-1}$ and it was coupled to nitrogen assimilation in the upper layer $(r=-0.80$; Table 1). Ammonification occurred in the upper layer of the inner box during the 9 to 13 September downwelling $\left(0.5 \pm 01 \mu \mathrm{M} \mathrm{N} \mathrm{d}^{-1}\right)$, it switched to net maximum assimilation rates during the subsequent 13 to 16 September upwelling $\left(-2.7 \pm 0.4 \mu \mathrm{M} \mathrm{N} \mathrm{d}^{-1}\right)$ and remained at about $-1.6 \pm 0.3 \mu \mathrm{M} \mathrm{N} \mathrm{d}^{-1}$ during the 16 to $26 \mathrm{Sep}-$ tember moderate upwelling period. On average over the 9 to 23 September period (Fig. 5h), ammonification in the lower layer of the inner box was $0.64 \mu \mathrm{M} \mathrm{N} \mathrm{d}^{-1}$, $3 / 5$ of which was oxidized to nitrate. Ammonification in the lower layer of the outer box accounted $0.22 \mu \mathrm{M} \mathrm{N}$ $\mathrm{d}^{-1}$, all of which was oxidized to nitrate. In the upper layer, average nitrogen assimilation rates were -1.29 and $-0.64 \mu \mathrm{M} \mathrm{N} \mathrm{d}^{-1}$ in the inner and outer box, respectively ( $\sim 60 \%$ as nitrate, $\sim 40 \%$ as ammonium). Consequently, in the inner box, $53 \%$ of the nitrate and $37 \%$ of the ammonium assimilated in the upper layer was produced in the lower layer. In the outer box, $63 \%$ of the nitrate assimilated in the upper layer was produced in the lower layer.

\section{DISCUSSION AND CONCLUSIONS}

\section{Ammonification and nitrification in the ría in relation to other coastal systems}

Estimated nitrification rates in the lower layer of the Ría de Vigo range from undetectable to $1.4 \mu \mathrm{M} \mathrm{N} \mathrm{d}^{-1}$. These numbers became larger, up to $3.1 \mu \mathrm{M} \mathrm{N} \mathrm{d}^{-1}$, when the volume correction is applied. Considering the calculated flushing times (commonly 2 to $4 \mathrm{~d}$; see Appendix 1) and measured N-nutrient levels of the lower layer, nitrification is undoubtedly a key process to understand the short-time-scale evolution of $\mathrm{N}$ nutrients in the Ría de Vigo.

Net nitrification rates for the 2 study periods are in between the numbers expected for estuaries $(0$ to $70 \mu \mathrm{M} \mathrm{N} \mathrm{d}^{-1}$; see Kaplan 1983, Horrigan \& Springer 1990) and coastal seas (0.0 to $2.5 \mu \mathrm{M} \mathrm{N} \mathrm{d}^{-1}$; see Manguer et al. 1999 and references therein). They are much larger than those measured in open ocean oligotrophic waters, where maximum rates $\left(<0.2 \mu \mathrm{M} \mathrm{N} \mathrm{d}^{-1}\right)$ are usually found at the depth of the primary nitrite maximum (see Dore \& Karl 1996 and references therein). Increasing ammonium levels and greater turbidity (with particles reducing light penetration and provid-
Table 1. Analysis of the correlation among net ammonification and nitrification rates for the upper and lower layers of the Ría de Vigo during September 1990 and 1991. Model II regression was used (Sokal \& Rolf 1995). NS: not significant

\begin{tabular}{|llcllr|}
\hline Year & $Y$ & Slope & $X$ & $r$ & $\mathrm{~N}$ \\
\hline 1990 & $K_{\text {orgL }}$ & $\mathrm{NS}$ & $K_{\text {orgU }}$ & - & 8 \\
& $K_{1 \mathrm{~L}}$ & $\mathrm{NS}$ & $K_{1 \mathrm{U}}$ & - & 8 \\
& $K_{2 \mathrm{~L}}$ & $\mathrm{NS}$ & $K_{2 \mathrm{U}}$ & - & 8 \\
\multirow{1}{*}{1991} & $K_{\text {orgL }}$ & $-0.47 \pm 0.05$ & $K_{\text {orgU }}$ & -0.80 & 10 \\
& $K_{1 \mathrm{~L}}$ & $-0.67 \pm 0.09$ & $K_{1 \mathrm{U}}$ & -0.75 & 10 \\
& $K_{2 \mathrm{~L}}$ & $-0.67 \pm 0.09$ & $K_{2 \mathrm{U}}$ & -0.70 & 10 \\
$1990-1991$ & $K_{1 \mathrm{~L}}$ & $0.79 \pm 0.09$ & $K_{\text {orgL }}$ & 0.87 & 18 \\
& $K_{2 \mathrm{~L}}$ & $0.92 \pm 0.01$ & $K_{1 \mathrm{~L}}$ & 0.98 & 18 \\
& $K_{1 \mathrm{U}}$ & $0.62 \pm 0.03$ & $K_{\text {orgU }}$ & 0.97 & 18 \\
& $K_{2 \mathrm{U}}$ & $0.93 \pm 0.01$ & $K_{1 \mathrm{U}}$ & 0.99 & 18 \\
\hline
\end{tabular}

ing a substratum for ammonium-oxidizing bacteria) along the open ocean-coast gradient are the common reasons behind the differences in nitrification rates between estuarine, coastal and open ocean systems (Horrigan \& Springer 1990). In this sense, although ammonium levels in the lower layer of the Ría de Vigo (from 0.4 to $4.7 \mathrm{mmol} \mathrm{m}^{-3}$ ) are relatively high compared with the adjacent open ocean $\left(<0.1 \mathrm{mmol} \mathrm{m}^{-3}\right.$; Álvarez-Salgado et al. 1997), they are low when compared with the ammonium concentrations found in estuaries (Sharp 1983).

Nitrification rates in coastal upwelling systems are scarce in the literature. Castellví \& O'Shanahan (1977) were able to isolate and incubate marine nitrifying bacteria from the NW Africa coastal upwelling system, obtaining a net nitrification rate of about $0.5 \mu \mathrm{M} \mathrm{d}^{-1}$ after $10 \mathrm{~d}$ of incubations. Ward (1982) estimated nitrification rates on the order of $0.3 \mu \mathrm{M} \mathrm{d}^{-1}$ assuming optimal growth conditions for ammonium-oxidizing bacteria in coastal waters off Washington and California, although measured values were always $<40 \times 10^{-3} \mu \mathrm{M} \mathrm{d}^{-1}$ (Ward et al. 1984). Therefore, ammonium oxidation rates estimated in the Ría de Vigo should be considered high when compared with other coastal upwelling systems.

\section{Ammonification and nitrification in the ría in relation to the oceanographic conditions}

Pelagic and benthic ammonification and nitrification rates in the marine environment used to depend mainly on the supply of substrate rather than on the concentration of electron acceptors or on bacterial numbers. Although temperature was also revealed as a relevant environmental control variable (von Brand et al. 1942, Kaplan 1983), the range of temperatures in the lower layer of the Ría de Vigo during September 1990 and 
1991, from 14.1 to $17.6^{\circ} \mathrm{C}$, did not produce a significant dependence of nitrification processes on temperature $(r<0.32, \mathrm{p}>0.16)$. Good agreement should be expected between the net production of organic nitrogen in the upper layer $\left(=-K_{\text {orgU }}\right)$ and the net ammonification $\left(K_{\text {orgL }}\right)$ and nitrification $\left(K_{1 \mathrm{~L}}\right.$ and $\left.K_{2 \mathrm{~L}}\right)$ rates in the lower layer. A study of the correlation among $K_{\text {org }}, K_{1}$ and $K_{2}$ between the upper and lower layers of the ría yielded that decoupling existed during September 1990 (Table 1). On the contrary, the rates were significantly coupled during September $1991(r<-0.70$, $\mathrm{p}>0.001$ ). The slopes of the regression lines indicate that $47 \pm 5 \%$ of the inorganic $\mathrm{N}\left(\mathrm{NH}_{4}{ }^{+}+\mathrm{NO}_{2}{ }^{-}+\mathrm{NO}_{3}{ }^{-}\right)$ consumed in the upper layer was produced in the lower layer of the ría. In the case of the oxidized forms of $\mathrm{N}\left(\mathrm{NO}_{2}{ }^{-}+\mathrm{NO}_{3}{ }^{-}\right), 67 \pm 9 \%$ of the amount consumed in the upper layer was produced in the lower layer. A previous study of the relationship between the abundance of bacteria and the hydrographic variability of the Ría de Vigo revealed that a strong coupling exists between primary production in the photic layer and bacterial growth in the aphotic layer (Zdanowski \& Figueiras 1997). For the case of nitrification, a linear relationship should be expected between ambient $\mathrm{NH}_{4}{ }^{+}$ concentrations and nitrification rates, when ammonium levels are below saturating concentrations (Ward et al. 1984). Since no correlation was found between $\mathrm{NH}_{4}{ }^{+}$concentrations in the lower layer of the ría and $K_{1}$ or $K_{2}(r<0.03, \mathrm{p}>0.46)$, it can be concluded that ammonium oxidizing bacteria are not substrate limited in the Ría de Vigo.

Transition from the upwelling- to the downwellingfavorable season in the NW Iberian margin usually occurs from mid-September to mid-October (Nogueira et al. 1997). Such a transition is common in all coastal upwelling systems at temperate latitudes (California and Chile; Bakun \& Nelson 1991). Consequently, either coastal upwelling or downwelling can be dominant at this time of the year, with contrasting biogeochemical consequences. In fact, September 1990 and 1991 were quite different from an oceanographic point of view.

In 1990, the survey period coincided with the transition from the upwelling- to the downwelling-favorable season, upwelling being dominant from 14 to 20 September and downwelling from 20 to 27 September (Gilcoto et al. 2001). These transitional conditions led to reduced biogeochemical activity: net production of organic nitrogen in the upper layer only was relatively important in the outer box from 18 to 20 September and in the inner box from 20 to 24 September, i.e. during the spin-down phase of upwelling in the outer and inner box, respectively. On the other hand, maximum regeneration rates in the lower layer of either the inner or the outer box were recorded during the down- welling period of 24 to 27 September, when net primary production in the upper layer was nil. Therefore, regeneration of the organic $\mathrm{N}$ produced in the upper layer occurred in the lower layer at time scales longer than the flushing times of the ría $(<4 \mathrm{~d}$; see Appendix 1$)$. This sequence of dominance of $\mathrm{N}$ assimilative processes during the spin down phase of upwelling and dominance of $\mathrm{N}$-regeneration processes during the subsequent downwelling conditions has already been described for the NW Iberian Peninsula (Moncoiffé et al. 2000).

In 1991, after a brief downwelling period from 9 to 13 September, when N-regeneration processes were dominant either in the upper or lower layer of the inner and outer Ría de Vigo, moderate but sustained upwelling occurred from 13 to 26 September. It was during this $\sim 2$ wk period of upwelling that a remarkable coupling between $\mathrm{N}$-assimilation in the upper layer and N-regeneration in the lower layer was inferred at the short time scale of the flushing times (normally between 2 and $4 d_{\text {; }}$ see Appendix 1). In this sense, it has been demonstrated that moderate upwelling produces the adequate balance between nutrient supply and flushing rate for the efficient consumption of upwelled N nutrients (Huntsman \& Barber 1977, Wroblewski \& Hoffmann 1989, Álvarez-Salgado et al. 1996).

\section{Ammonification and nitrification in relation to coastal new and regenerated production}

The dimensions (volume, $V$ ) and the extension of the exchange with the surroundings (water flows, $\sum_{i} Q_{i \prime}$ with $i$ being any flow entering the volume) determines the time scales involved in the metabolic balance of any ecosystem. The ratio $V / \sum_{i} Q_{i}$ i.e. the flushing time, is the best indicator of such time scales. Within this context, any catabolic process occurring at the time scale of the flushing period should be considered part of the regenerated production of the ecosystem. On the other hand, the balance of primary production minus these catabolic processes (the net ecosystem production) could be equated to the new production, i.e. the fraction of primary production that is sustained by the entry of the limiting nutrient from the external boundaries of the ecosystem. Consequently, any catabolic process occurring at time scales larger than the flushing period usually occur outside the boundaries of the ecosystem and should be part of the new production.

$\mathrm{N}$ is commonly the limiting nutrient of primary production in marine environments in general (Howarth 1988) and in coastal upwelling systems in particular (Codispoti 1983), except in some particular cases when silicate can became limiting (Dugdale et al. 1995). Consequently, ammonification and nitrification pro- 
cesses, as part of the nitrogen catabolism, tend to reduce the new production of the ecosystem. Although ammonification and nitrification occur either in the photic or the aphotic zone (Wafar et al. 1995), the dominance of ammonium assimilation over regeneration and the light inhibition of nitrification processes (Oslon 1981, Ward et al. 1982, Wada \& Hattori 1991) show that both catabolic processes take place mainly in the aphotic layer.

In the case of the inner and outer Ría de Vigo, flushing times of the upper and lower layers usually range from 2 to $4 \mathrm{~d}$, although exceptionally large values $>7 \mathrm{~d}$ occur during prolonged upwelling-relaxation or downwelling periods. According to the classical definition of regenerated and new production (Dugdale \& Goering 1967), ammonification and nitrification processes occurring in the lower layer of the ría should be considered part of the new production of the upper layer, since production of $\mathrm{N}$ nutrients by these catabolic processes occurs outside the boundaries of the system. However, when the time scale of processes is also considered, the concepts of new and regenerated production can be altered. During September 1990, ammonification and nitrification in the lower layer occured at a different time scale than $\mathrm{N}$ assimilation in the upper layer, and therefore, they should be part of the new production of the ecosystem. On the contrary, during September 1991, assimilation and regeneration processes in the upper and lower layers were coupled at the time scale of the flushing times. This means that the fraction of the inorganic $\mathrm{N}$ assimilated in the upper layer that had been regenerated in the lower layer was produced from detritus originating from the same community that was assimilating $\mathrm{N}$ in the upper layer. Consequently, it should be considered part of the regenerated production of the upper layer, although it was produced in the lower layer of the ría.

It is also important to note that the definition of new and regenerated production given by Eppley \& Peterson (1979) for the open ocean is not operative for coastal systems, as previously noted by Wollast (1993). Following Eppley \& Peterson (1979), the new production of an ecosystem is fed by nitrate and the regenerated production by ammonium. The results obtained in the Ría de Vigo indicate that both nitrate and ammonium are assimilated in the upper layer and regenerated in the lower layer. Consequently, part of the new production can be supported by ammonium and part of the regenerated production can be supported by nitrate.

Acknowledgements. The authors wish to thank the crew and scientific parties that joined the surveys to the Ría de Vigo during September 1990 and 1991 onboard the RV 'Explo- rador'. Special thanks to B. M. Míguez for the calculation of average tracer concentrations in boxes and boundaries and to T. Rellán for dissolved oxygen analyses. Three anonymous reviewers contributed to improve an earlier version of the manuscript. Support for this work came from the EU project MAST-CT90-0017 (The Control of Phytoplankton Dominance).

\section{LITERATURE CITED}

Álvarez-Salgado XA, Rosón G, Pérez FF, Pazos Y (1993) Hydrographic variability off the Rías Baixas (NW Spain) during the upwelling season. $\mathrm{J}$ Geophys Res 98: 14447-14455

Álvarez-Salgado XA, Rosón G, Pérez FF, Figueiras GF, Pazos $Y$ (1996) Nitrogen cycling in an estuarine upwelling system, the Ría de Arousa (NW Spain). I. Short-time-scale patterns of hydrodynamic and biogeochemical circulation. Mar Ecol Prog Ser 135:259-273

Álvarez-Salgado XA, Castro CG, Pérez FF, Fraga F (1997) Nutrient mineralization patterns in shelf waters of the Western Iberian upwelling. Cont Shelf Res 17:1247-1270

Álvarez-Salgado XA, Gago J, Míguez BM, Gilcoto M, Pérez FF (2000) Surface waters of the NW Iberian margin: upwelling on the shelf versus outwelling of upwelled waters from the Rías Baixas. Estuar Coast Shelf Sci 51: 821-837

Anderson LA (1995) On the hydrogen and oxygen content of marine phytoplankton. Deep-Sea Res I 42:1675-1680

Bakun A, Nelson CS (1991) The seasonal cycle of wind-stress curl in subtropical eastern boundary current regions. J Phys Oceanogr 21:1815-1834

Cabanas JM, González N, González JJ, García Fernández C (1983) Nutrientes en la Ría de Arosa: Distribución e interrelación. Bol Inst Esp Oceanogr 1:72-84

Carlucci AF, Strickland JDH (1968) The isolation, purification and some kinetic studies of marine nitrifying bacteria. J Exp Mar Biol Ecol 2:156-166

Castellví J, O'Shanahan L (1977) Nitrificación heterotrófica por bacterias marinas. Investig Pesq (Barc) 41:501-507

Codispoti LA (1983) Nitrogen in upwelling systems. In: Carpenter EJ, Capone DG (eds) Nitrogen in the marine environment. Academy Press, New York, p 513-564

Dore EJ, Karl DM (1996) Nitrification in the euphotic zone as a source for nitrite, nitrate and nitrous oxide at Station ALOHA. Limnol Oceanogr 41:1619-1628

Dugdale RC, Goering J (1967) Uptake of new and regenerated forms of nitrogen in primary production. Limnol Oceanogr 12:196-206

Dugdale RC, Wilkerson FP, Minas HJ (1995) The role of a silicate pump in driving new production. Deep-Sea Res I 42: $697-719$

Eppley RW, Peterson BJ (1979) Particulate organic matter flux and planktonic new production in the deep ocean. Nature 282:677-680

Fraga F (1960) Variación estacional de la materia orgánica suspendida y disuelta en la Ría de Vigo. Influencia de la luz y la temperatura. Investig Pesq (Barc) 17:127-140

Fraga F (1961) La descomposición de la materia orgánica nitrogenada en el mar. Investig Pesq (Barc) 19:65-79

Fraga F (1967) Hidrografía de la Ría de Vigo, 1962, con especial referencia a los compuestos de nitrógeno. Investig Pesq (Barc) 31:145-159

Fraga F, Vives F (1961) Variación estacional de la materia orgánica en la Ría de Vigo. Investig Pesq (Barc) 20:65-71

Fraga F, Pérez FF, Figueiras FG, Ríos AF (1992) Stoichiomet- 
ric variations of N, P, C and O2 during a Gymnodinium catenatum red tide and their interpretation. Mar Ecol Prog Ser 87:123-134

Gilcoto M, Álvarez-Salgado XA, Pérez FF (2001) Computing Optimum Estuarine Residual Fluxes with a Multiparameter Inverse Method (OERFIM). Application to the Ría de Vigo (NW Spain). J Geophys Res 106:31303-31318

González N, González JJ, García C, Cabanas JM (1979) Dinámica de nutrientes en las rías de Arosa y muros (NW España). Bol Inst Esp Oceanogr 5:53-79

Guerrero MA, Jones RD (1996a) Photoinhibition of marine nitrifying bacteria. I. Wavelength-dependent response. Mar Ecol Prog Ser 141:183-192

Guerrero MA, Jones RD (1996b) Photoinhibition of marine nitrifying bacteria. II. Dark recovery after monochromatic or polychromatic irradiation. Mar Ecol Prog Ser 141: 193-198

Hansen HP, Grasshoff K (1983) Automated chemical analysis. In: Grasshoff K, Ehrhardt M, Kermling K (eds) Methods of seawater analysis, 2nd edn. Verlag Chemie, Weinheim, p 347-395

Harrison WG (1980) Nutrient regeneration and primary production in the sea. In: Falkowski PG (ed) Primary productivity in the sea. Plenum Press, New York, p 433-460

Horrigan SG, Springer AL (1990) Oceanic and estuarine ammonium oxidation: Effects of light. Limnol Oceanogr 35:479-482

Howarth RW (1988) Nutrient limitation of net primary production in marine ecosystems. An Rev Ecol Syst 19:89-110

Huntsman SA, Barber RT (1977) Primary production off northwest Africa: the relationship to wind and nutrient conditions. Deep-Sea Res 24:25-33

Iglesias ML, Nunes MT (1982) Variación anual de algunos parámetros físico-químicos en la Ría de Arosa. Bol Inst Esp Oceanogr 7:181-190

Kaplan WA (1983) Nitrification. In: Carpenter EJ, Capone FG (eds) Nitrogen in the marine environment. Academic Press, New York, p 139-190

Klump JV, Martens CS (1983) Benthic nitrogen regeneration. In: Carpenter EJ, Capone FG (eds) Nitrogen in the Marine environment. Academic Press, New York, p 411-457

Legendre L, Rassoulzadegan F (1995) Plankton and nutrient dynamics in marine waters. Ophelia 41:153-172

Maamaatuaiahutapu K, Garçon VC, Provost C, Boulahdid M, Osiroff AP (1992) Brazil-Malvinas confluence: water mass composition. J Geophys Res 97:9493-9505

Manguer JF, L'Helgu S, Madec C, Le Corre P (1999) Seasonal patterns of ammonium regeneration from size-fractionated microheterotrophs. Cont Shelf Res 19:1755-1770

Middelburg JJ, Vlug T, Jaco F, van der Nat WA (1993) Organic matter mineralization in marine systems. Global Planet Change 8:47-58

Moncoiffé G, Álvarez-Salgado XA, Figueiras FG, Savidge G (2000) Seasonal and short-time-scale dynamics of microplankton community production and respiration in an inshore upwelling system. Mar Ecol Prog Ser 196: $111-126$

Mouriño C, Fraga F (1985) Determinación de nitratos en agua de mar. Investig Pesq (Barc) 49:81-96

Nogueira E, Pérez FF, Ríos AF (1997) Seasonal patterns and long-term trends in an estuarine upwelling ecosystem (Ría de Vigo, NW Spain). Estuar Coast Shelf Sci 44:285-300

Nogueira E, Pérez FF, Ríos AF (1998) Modelling nutrients and chlorophyll a time series in an estuarine upwelling ecosystem (Ría de Vigo: NW Spain) using the Box-Jenkins approach. Estuar Coast Shelf Sci 46:267-286

Olson RJ (1981) Differential photoinhibition of marine nitrify- ing bacteria: a possible mechanism for the formation of the primary nitrite maximum. J Mar Res 39:227-238

Pérez FF, Álvarez-Salgado XA, Rosón G, Ríos AF (1992) Carbonic-calcium system, nutrients and total organic nitrogen in continental runofrf to the Galician Rias Baixas, NW Spain. Oceanol Acta 15:595-602

Prego R (1994) Nitrogen interchanges generated by biogeochemical processes in a Galician Ría. Mar Chem 45: $167-176$

Ríos AF, Nombela MA, Pérez FF, Rosón G, Fraga F (1992) Calculation of runoff to an estuary, Ría de Vigo. Sci Mar 56:29-33

Sharp JH (1983) The distributions of inorganic nitrogen and dissolved and particulate organic nitrogen in the sea. In: Carpenter EJ, Capone DG (eds) Nitrogen in the marine environment. Academy Press, New York, p 1-64

Smith SV, Hollibaugh JT (1993) Coastal metabolism and the oceanic organic carbon balance. Rev Geophys 31:75-89

Smith SV, Hollibaugh JT (1997) Annual cycle and interannual variability of ecosystem metabolism in a temperate climate embayment. Ecol Monogr 67:509-533

Sokal RR, Rolhf FJ (1995) Biometry. WH Freeman, New York

Tenore KR, Boyer LF, Cal RM, García Fernández C and 10 others (1982) Coastal upwelling in the Rías Baixas, NW Spain. Contrasting the benthic regimes of the Ría de Arousa and Muros. J Mar Res 40:701-772

UNESCO (1985) The international system of units (SI) in oceanography. UNESCO Tech Pap Mar Sci

von Brand T, Rakestraw NW, Renn CE (1937) The experimental decomposition and regeneration of nitrogenous organic matter in sea water. Biol Bull (Woods Hole) 72:165-175

von Brand T, Rakestraw NW, Renn CE (1939) Further experiments on the decomposition and regeneration of nitrogenous organic matter in sea water. Biol Bull (Woods Hole) 77:285-296

von Brand T, Rakestraw NW (1940) Decomposition and regeneration of nitrogenous organic matter in seawater. III. Influence of temperature and source and condition of water. Biol Bull (Woods Hole) 79:231-236

von Brand T, Rakestraw NW (1941) Decomposition and regeneration of nitrogenous organic matter in seawater. IV. Interrelationships of various stages; influence of concentration and nature of particulate matter. Biol Bull (Woods Hole) 81:63-69

von Brand T, Rakestraw NW, Zabor JW (1942) Decomposition and regeneration of nitrogenous organic matter in seawater. V. Factors influencing the length of the cycle; observations upon the gaseous and dissolved organic nitrogen. Biol Bull (Woods Hole) 83:273-282

Wada E, Hattori A (1991) Nitrogen in the Sea: forms, abundances, and rate processes. CRC Press, Boca Raton, FL

Wafar MVM, Le Corre P, L'Helguen S (1995) f-Ratios calculated with and without urea uptake in nitrogen uptake by phytoplankton. Deep-Sea Res 42:1669-1774

Ward BB (1982) Oceanic distribution of ammonium-oxidizing bacteria determined by immunofluorescent assay. J Mar Res 40:1155-1172

Ward BB, Olson RJ, Perry MJ (1982) Microbial nitrification rates in the primary nitrite maximum off southern California. Deep-Sea Res 29:247-255

Ward BB, Talbot MC, Perry MJ (1984) Contributions of phytoplankton and nitrifying bacteria to ammonium and nitrite dynamics in coastal waters. Cont Shelf Res 3:383-398

Watson SW (1965) Characteristics of a marine nitrifying bacterium, Nitrosocystis oceanus sp. n. Limnol Oceanogr 10: $274-289$

Winogradsky S (1890) Recherches sur les organismes de la 
nitrification. Comput Rendu 110:1013-1016

Wollast R (1993) Interactions of carbon and nitrogen cycles in the coastal zone. In: Wollast R, Mackenzie FP, Chou L (eds) Interaction of C, N, P and S biochemical cycles and global change. Springer-Verlag, Berlin, p 195-210

Wroblewski JS, Hofmann EE (1989) U.S. interdisciplinary modelling studies of coastal-offshore exchange processes: past and future. Prog Oceanogr 23:65-99
Yoshida Y (1967) Studies on the marine nitrifying bacteria: with special reference to characteristics and nitrite formation of marine nitrite formers. Bull Misaki Mar Biol Inst Kyoto Univ 11:2-58

Zdanowski MK, Figueiras FG (1997) Relationships between the abundance of bacteria and other biota and the hydrographic variability in the Ría de Vigo, Spain. Mar Ecol Prog Ser 147:257-267

Appendix 1. Horizontal surface and bottom velocities and vertical advection and turbulent diffusion velocities and their errors in the inner and outer boxes of the Ría de Vigo during September 1990 and 1991 (flushing time, $f=\frac{V}{\sum_{i} Q_{i}}$, where $V$ is the vol-
ume and $\sum_{i} Q_{i}$ the sum of all flows entering the volume)

\begin{tabular}{|c|c|c|c|c|c|c|c|c|}
\hline \multirow[t]{2}{*}{ Year } & \multirow[t]{2}{*}{ Dates } & \multirow[t]{2}{*}{ Box } & \multirow{2}{*}{$\begin{array}{c}V_{\mathrm{B}} \\
\left(\mathrm{km} \mathrm{d}^{-1}\right)\end{array}$} & \multirow{2}{*}{$\begin{array}{c}V_{\mathrm{S}} \\
\left(\mathrm{km} \mathrm{d}^{-1}\right)\end{array}$} & \multirow{2}{*}{$\left(\begin{array}{c}V_{\mathrm{Z}} \\
\left(\mathrm{m} \mathrm{d}^{-1}\right)\end{array}\right.$} & \multirow{2}{*}{$\begin{array}{c}V_{\mathrm{M}} \\
\left(\mathrm{m} \mathrm{d}^{-1}\right)\end{array}$} & \multicolumn{2}{|c|}{$f(\mathrm{~d})$} \\
\hline & & & & & & & Upper & Lower \\
\hline \multirow[t]{8}{*}{1990} & $14-18$ & Inner & $1.9 \pm 0.3$ & $1.9 \pm 0.2$ & $1.0 \pm 0.2$ & $0.3 \pm 0.2$ & $5.7 \pm 0.8$ & $3.0 \pm 0.3$ \\
\hline & $18-20$ & & $2.3 \pm 0.3$ & $3.5 \pm 0.5$ & $1.7 \pm 0.3$ & $0.6 \pm 0.3$ & $2.8 \pm 0.3$ & $2.2 \pm 0.2$ \\
\hline & $20-24$ & & $-1.9 \pm 0.4$ & $-1.9 \pm 0.4$ & $-0.8 \pm 0.3$ & $0.3 \pm 0.3$ & $4.7 \pm 0.8$ & $4.4 \pm 1.1$ \\
\hline & $24-27$ & & $-1.5 \pm 0.5$ & $-1.1 \pm 0.3$ & $-1.0 \pm 0.2$ & $0.1 \pm 0.1$ & $8.8 \pm 1.5$ & $3.4 \pm 0.5$ \\
\hline & $14-18$ & Outer & $2.0 \pm 0.3$ & $3.2 \pm 0.4$ & $1.5 \pm 0.4$ & $0.6 \pm 0.6$ & $3.7 \pm 0.3$ & $3.9 \pm 0.5$ \\
\hline & $18-20$ & & $1.4 \pm 0.3$ & $2.0 \pm 0.4$ & $0.6 \pm 0.4$ & $0.5 \pm 0.4$ & $3.2 \pm 0.4$ & $6.4 \pm 0.7$ \\
\hline & $20-24$ & & $-2.9 \pm 0.6$ & $-3.2 \pm 06$ & $-1.7 \pm 0.7$ & $0.7 \pm 0.7$ & $2.8 \pm 0.5$ & $4.6 \pm 1.1$ \\
\hline & $24-27$ & & $-3.0 \pm 0.6$ & $-3.7 \pm 0.7$ & $-3.5 \pm 0.8$ & $0.7 \pm 0.7$ & $3.2 \pm 0.5$ & $2.5 \pm 0.4$ \\
\hline \multirow[t]{10}{*}{1991} & $9-13$ & Inner & $-0.7 \pm 0.1$ & $-0.6 \pm 0.1$ & $-0.4 \pm 0.1$ & $0.1 \pm 0.1$ & $12.0 \pm 0.8$ & $9.2 \pm 0.7$ \\
\hline & $13-16$ & & $3.1 \pm 0.5$ & $3.2 \pm 0.5$ & $1.8 \pm 0.3$ & $2.9 \pm 0.7$ & $1.4 \pm 0.2$ & $1.0 \pm 0.1$ \\
\hline & $16-19$ & & $1.6 \pm 0.2$ & $2.2 \pm 0.3$ & $1.0 \pm 0.2$ & $1.2 \pm 0.3$ & $2.6 \pm 0.2$ & $2.3 \pm 0.2$ \\
\hline & $19-24$ & & $1.4 \pm 0.2$ & $2.1 \pm 0.3$ & $1.2 \pm 0.1$ & $1.5 \pm 0.2$ & $2.1 \pm 0.2$ & $2.2 \pm 0.2$ \\
\hline & $24-26$ & & $1.8 \pm 0.3$ & $2.7 \pm 0.4$ & $1.6 \pm 0.2$ & $2.3 \pm 0.5$ & $1.6 \pm 0.1$ & $1.5 \pm 0.1$ \\
\hline & $9-13$ & Outer & $-2.5 \pm 0.4$ & $-2.5 \pm 0.4$ & $-2.2 \pm 0.5$ & $0.4 \pm 0.4$ & $3.8 \pm 0.5$ & $4.5 \pm 0.5$ \\
\hline & $13-16$ & & $4.8 \pm 0.6$ & $5.1 \pm 0.7$ & $3.8 \pm 0.8$ & $0.3 \pm 1.1$ & $2.5 \pm 0.3$ & $2.1 \pm 0.3$ \\
\hline & $16-19$ & & $2.5 \pm 0.3$ & $3.2 \pm 0.3$ & $2.7 \pm 0.4$ & $1.3 \pm 0.5$ & $2.4 \pm 0.2$ & $3.2 \pm 0.3$ \\
\hline & $19-24$ & & $2.1 \pm 0.3$ & $3.3 \pm 0.5$ & $2.1 \pm 0.5$ & $0.8 \pm 0.4$ & $2.9 \pm 0.3$ & $4.1 \pm 0.5$ \\
\hline & $24-26$ & & $0.9 \pm 0.1$ & $1.2 \pm 0.2$ & $2.1 \pm 0.2$ & $0.3 \pm 0.8$ & $3.4 \pm 0.4$ & $10.3 \pm 3.4$ \\
\hline
\end{tabular}

Appendix 2. Upper (U) and lower (L) layer $K_{\text {org }} K_{1}$ and $K_{2}$ values $\left(\mu \mathrm{M} \mathrm{N} \mathrm{d}^{-1}\right.$ ) and their errors in the inner and outer boxes of the Ría de Vigo during September 1990 and 1991. $K_{\text {org, }} K_{1}$ and $K_{2}$ are based on the volume of the entire inner and outer boxes to facilitate comparison between the upper and lower layers. To obtain rates based on upper and lower layer volumes, these numbers should be multiplied by $1.7 \pm 0.2$ and $2.2 \pm 0.4$ for the inner box and by $2.4 \pm 0.4$ and $1.9 \pm 0.3$ for the outer box, respectively

\begin{tabular}{|c|c|c|c|c|c|c|c|c|}
\hline Year & Dates & Box & $K_{\mathrm{orgL}}$ & $K_{\text {orgU }}$ & $K_{1 \mathrm{~L}}$ & $K_{1 \mathrm{U}}$ & $K_{2 \mathrm{~L}}$ & $K_{2 \mathrm{U}}$ \\
\hline \multirow[t]{8}{*}{1990} & $14-18$ & Inner & $-0.1 \pm 0.1$ & $0.4 \pm 0.1$ & $-0.2 \pm 0.1$ & $0.0 \pm 0.1$ & $-0.2 \pm 0.1$ & $0.0 \pm 0.1$ \\
\hline & $18-20$ & & $0.1 \pm 0.2$ & $-0.1 \pm 0.2$ & $-0.1 \pm 0.1$ & $0.1 \pm 0.1$ & $-0.1 \pm 0.1$ & $0.1 \pm 0.1$ \\
\hline & $20-24$ & & $0.2 \pm 0.1$ & $-0.8 \pm 0.1$ & $0.0 \pm 0.1$ & $-0.5 \pm 0.1$ & $0.0 \pm 0.1$ & $-0.4 \pm 0.1$ \\
\hline & $24-27$ & & $0.3 \pm 0.1$ & $-0.1 \pm 0.1$ & $0.1 \pm 0.1$ & $-0.1 \pm 0.1$ & $0.1 \pm 0.1$ & $-0.1 \pm 0.1$ \\
\hline & $14-18$ & Outer & $0.2 \pm 0.4$ & $0.0 \pm 0.3$ & $0.0 \pm 0.3$ & $0.0 \pm 0.2$ & $0.0 \pm 0.2$ & $0.0 \pm 0.2$ \\
\hline & $18-20$ & & $0.0 \pm 0.2$ & $-0.7 \pm 0.3$ & $-0.1 \pm 0.2$ & $-0.5 \pm 0.2$ & $-0.1 \pm 0.2$ & $-0.4 \pm 0.2$ \\
\hline & $20-24$ & & $-0.1 \pm 0.3$ & $-0.1 \pm 0.3$ & $0.0 \pm 0.3$ & $-0.1 \pm 0.3$ & $0.0 \pm 0.3$ & $-0.1 \pm 0.3$ \\
\hline & $24-27$ & & $0.6 \pm 0.3$ & $0.0 \pm 0.4$ & $0.4 \pm 0.3$ & $0.0 \pm 0.3$ & $0.4 \pm 0.3$ & $0.0 \pm 0.3$ \\
\hline \multirow[t]{10}{*}{1991} & $9-13$ & Inner & $0.1 \pm 0.1$ & $0.5 \pm 0.1$ & $-0.0 \pm 0.1$ & $0.2 \pm 0.1$ & $-0.0 \pm 0.1$ & $0.2 \pm 0.1$ \\
\hline & $13-16$ & & $1.2 \pm 0.3$ & $-2.7 \pm 0.4$ & $0.7 \pm 0.3$ & $-1.4 \pm 0.3$ & $0.7 \pm 0.3$ & $-1.3 \pm 0.3$ \\
\hline & $16-19$ & & $0.8 \pm 0.2$ & $-1.6 \pm 0.2$ & $0.3 \pm 0.1$ & $-1.1 \pm 0.2$ & $0.2 \pm 0.1$ & $-1.0 \pm 0.2$ \\
\hline & $19-24$ & & $0.6 \pm 0.2$ & $-1.4 \pm 0.2$ & $0.5 \pm 0.1$ & $-1.0 \pm 0.2$ & $0.4 \pm 0.1$ & $-0.9 \pm 0.2$ \\
\hline & $24-26$ & & $1.1 \pm 0.4$ & $-1.9 \pm 0.5$ & $1.4 \pm 0.2$ & $-1.3 \pm 0.3$ & $1.2 \pm 0.2$ & $-1.3 \pm 0.3$ \\
\hline & $9-13$ & Outer & $0.2 \pm 0.1$ & $0.3 \pm 0.1$ & $0.1 \pm 0.1$ & $0.2 \pm 0.1$ & $0.1 \pm 0.1$ & $0.2 \pm 0.1$ \\
\hline & $13-16$ & & $0.3 \pm 0.2$ & $-1.0 \pm 0.3$ & $0.4 \pm 0.2$ & $-0.7 \pm 0.3$ & $0.4 \pm 0.2$ & $-0.6 \pm 0.3$ \\
\hline & $16-19$ & & $0.5 \pm 0.2$ & $-1.0 \pm 0.2$ & $0.3 \pm 0.1$ & $-0.6 \pm 0.2$ & $0.2 \pm 0.1$ & $-0.6 \pm 0.2$ \\
\hline & $19-24$ & & $0.1 \pm 0.2$ & $-0.9 \pm 0.2$ & $0.1 \pm 0.1$ & $-0.6 \pm 0.2$ & $0.1 \pm 0.1$ & $-0.5 \pm 0.2$ \\
\hline & $24-26$ & & $0.3 \pm 0.4$ & $-0.8 \pm 0.4$ & $0.5 \pm 0.3$ & $-0.5 \pm 0.4$ & $0.7 \pm 0.2$ & $-0.3 \pm 0.3$ \\
\hline
\end{tabular}

